Geology of the

Oregon Buttes Area

Sweetwater, Sublette

And Fremont Counties

Southwestern Wyoming

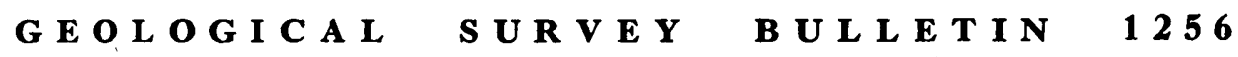

 Q

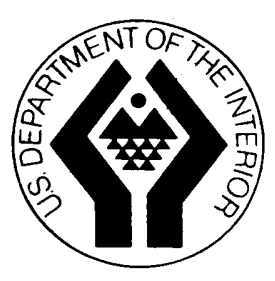

$4 \pm 75$

- 13.1256

C. 6 
-Geology of the

Oregon Buttes Area

Sweetwater, Sublette

And Fremont Counties

Southwestern Wyoming

By H. D. ZELLER and E. V. STEPHENS

GEOLOGICAL S U R V E Y B U L L E T I N 1256

- Investigations of an area that includes South Pass, where the historic Emigrant Trail crosses the Continental Divide

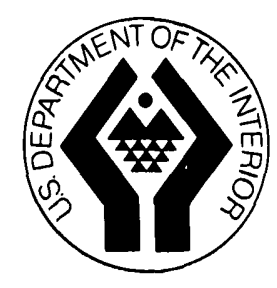




\section{UNITED STATES DEPARTMENT OF THE INTERIOR}

STEWART L. UDALL, Secretary

\section{GEOLOGIGAL SURVEY}

William T. Pecora, Director

Library of Congress catalog-card No. GS 68-281

For sale by the Superintendent of Documents, U.S. Government Printing Office Washington, D.C. 20402 


\section{CONTENTS}

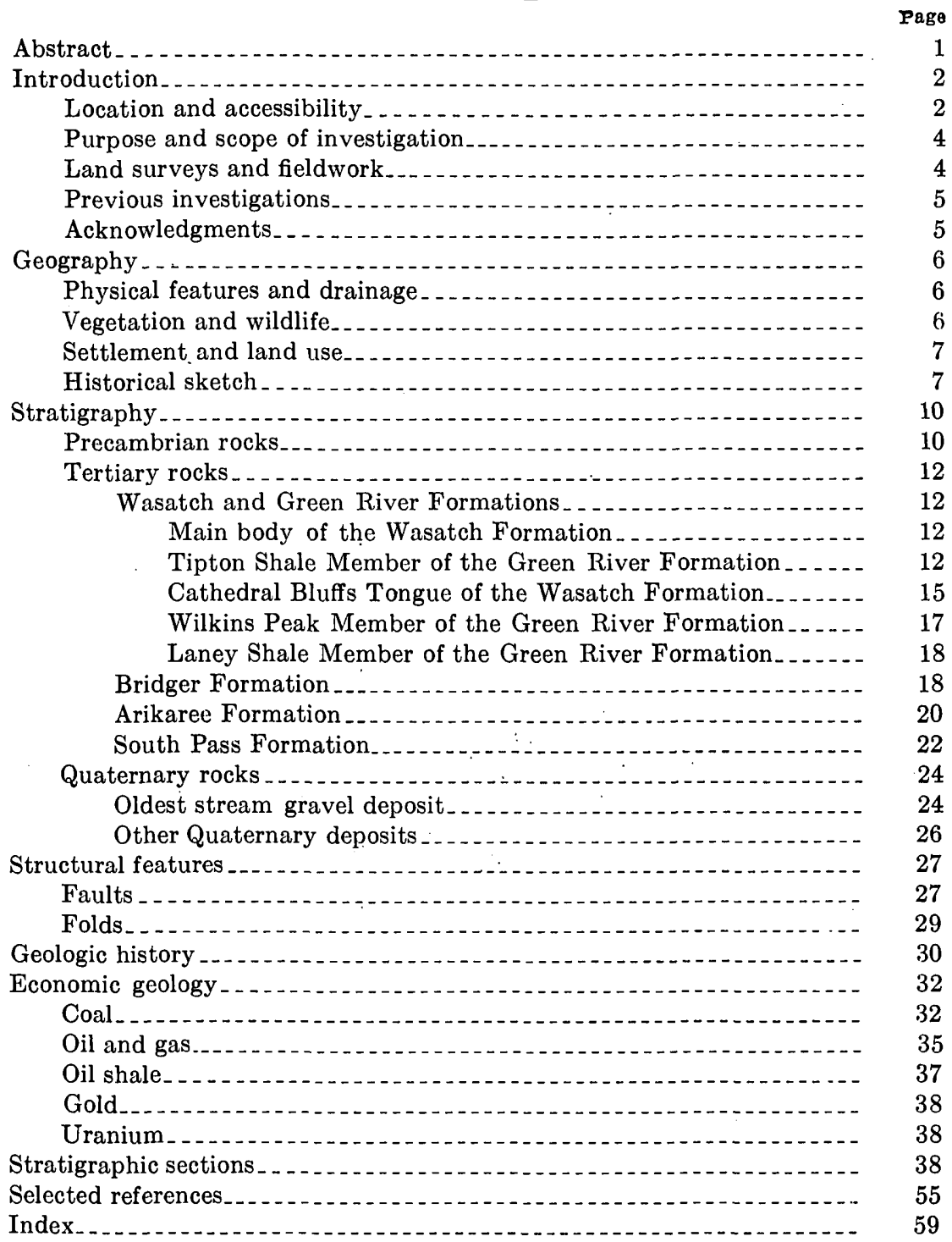




\section{ILLUSTRATIONS}

Page

Plate 1. Geologic map of the Oregon Buttes area, southwestern Wyoming .............. In pocket

2. Generalized graphic section of exposed rock in the Oregon Buttes area, Wyoming.......................

Figure 1. Index map showing location of Oregon Buttes area and regional structural features.......................

2. Photograph showing panoramic view north from Oregon

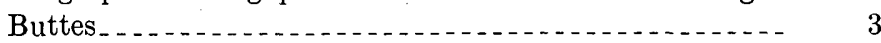

3. Correlation diagram of stratigraphic sections

4-7. Photographs of:

4. Cathedral Bluffs Tongue of Wasatch Formation _. _ _ 15

5. Fossil tree, Bridger Formation

6. Arikaree and Bridger Formations exposed on Oregon Buttes................................ 20

7. Basal conglomerate of Arikaree Formation ....... 21

8. Map showing possible drainageway during early Pleistocene time

9. Chart of distribution and depth of coal beds ......... 33

\section{TABLES}

TABLE

1. Generalized descriptive section of exposed Tertiary rocks,

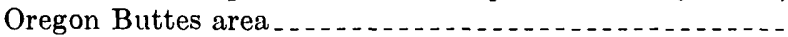

2. Analyses of samples of coal obtained from oil test holes in Oregon Buttes area and areas to the south............

3. Wells drilled for oil and gas in the Oregon Buttes area.......

4. Oil-shale assays from the U.S. Geological Survey Pinnacles 1 A core hole in the SW $1 \frac{1}{4}$ sec. 10, T. 26 N., R. 99 W.,

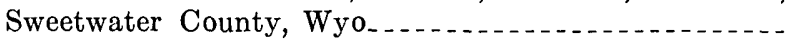




\title{
GEOLOGY OF THE OREGON BUTTES AREA SWEETWATER, SUBLETTE, AND FREMONT COUNTIES SOUTHWESTERN WYOMING
}

\author{
By H. D. Zeller and E. V. Stephens \\ ABSTRACT
}

The Oregon Buttes area includes about 550 square miles south of the Wind River Range and north of the Rock Springs uplift in southwestern Wyoming. The Continental Divide separates an eastern part included in the Great Divide Basin from a western pant included in the Green River Basin.

Except for scattered patches of crystalline rocks of Precambrian age including granite, diabase, and metagraywacke, which crop out along the north margin of the area, the exposed rocks are Tertiary sedimentary rocks. The oldest exposed sedimentary rock unit is the Wasatch Formation of early and middle Eocene age. The Wasatch is about 3,200 feet thick in the area. Other Eocene rocks, in ascending order above the Wasatch Formation, include the Tipton Shale Member of the Green River Formation, 0-300 feet thick; the Cathedral Bluffs Tongue of the Wasatch Formation, 0-200 feet thick; the Wilkins Peak Member of the Green River Formation, 0-35 feet thick; the Laney Shale Member of the Green River Formation, 90-250 feet thick; and the Bridger Formation, 500-800 feet thick. The Miocene Arikaree Formation, about 750 feet thick, unconformably overlies the Bridger Formation and is in turn unconformably overlain by about 350 feet of the conglomeratic South Pass Formation of late Miocene and Pliocene age.

Surficial deposits include a few widely spaced remnants of high-level terrace gravel. These deposits suggest that an ancient drainageway extended south into the Killpecker Creek valley in early Pleistocene time.

Two large-scale west-northwest-trending faults occur in the area. The Continental fault, a normal fault with about 1,400 feet of displacement, parallels the southwest flank of the Wind River Range. The fault crosses the northern part of the Oregon Buttes area and is the dominant exposed structural feature. The buried trace of the Wind River thrust fault is about 2 miles north of Oregon Buttes.

Folds in the area are scarce, but the northern part of the Rock Springs anticline extends into the southern part of the map area near Rock Cabin Creek and Jack Morrow Hills. The Reds Cabin monocline lies along the trace of the buried Wind River thrust, and post-Bridger Formation movement along the fault may have formed the monocline.

The southern half of the map area is underlain by coal beds at least 10 feet thick at an average depth of 3,000 feet, as revealed by logs of deep wells. The coal beds occur in the Paleocene Fort Union Formation. Coal beds in the Mesaverde Formation of Cretaceous age occur at depths greater than 5,000 feet. Structures in the area indicate a good potential for oil and gas production. A 
possible source of oil may exist in Paleocene and Cretaceous rocks in the lower plate of the Wind River fault. Placer gold deposits occur in alluvial deposits on the north side of the Continental fault near Dickie Springs.

\section{INTRODUCTION \\ LOCATION AND ACCESSIBILITY}

The Oregon Buttes area includes about 550 square miles (figs. 1,2) south of the Wind River Range and north of the Rock Springs uplift in southwestern Wyoming. The Continental Divide separates an eastern part included in the Great Divide Basin from a western part included in the Green River Basin. About 305 square miles in the southern part of the area is in Sweetwater County, about 165 square miles in the northeastern part is in Fremont County, and about 80 square miles in the northwestern part is in Sublette County.

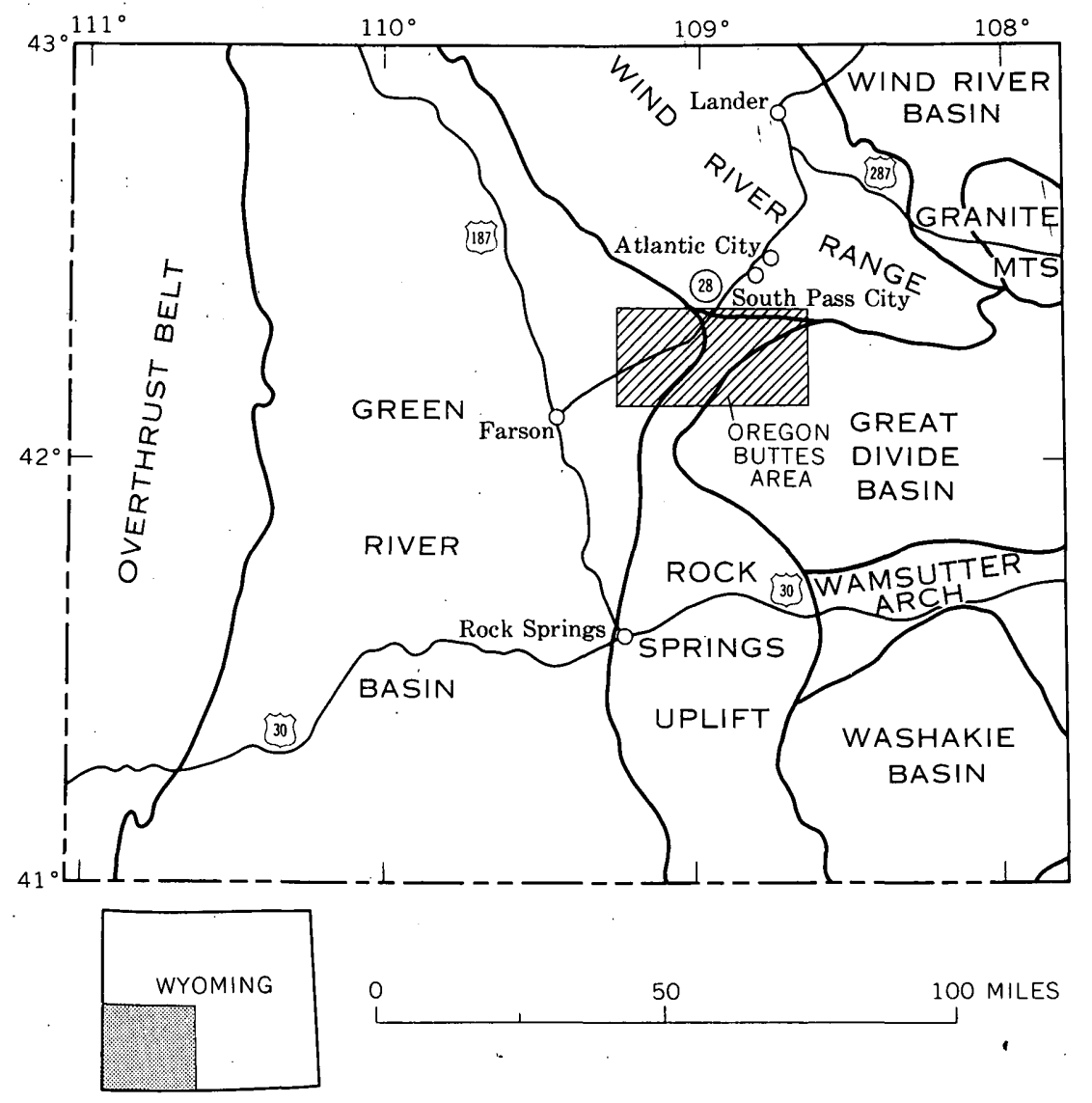

Figure 1.-Map showing location of the Oregon Bultes area and regional structural features. 


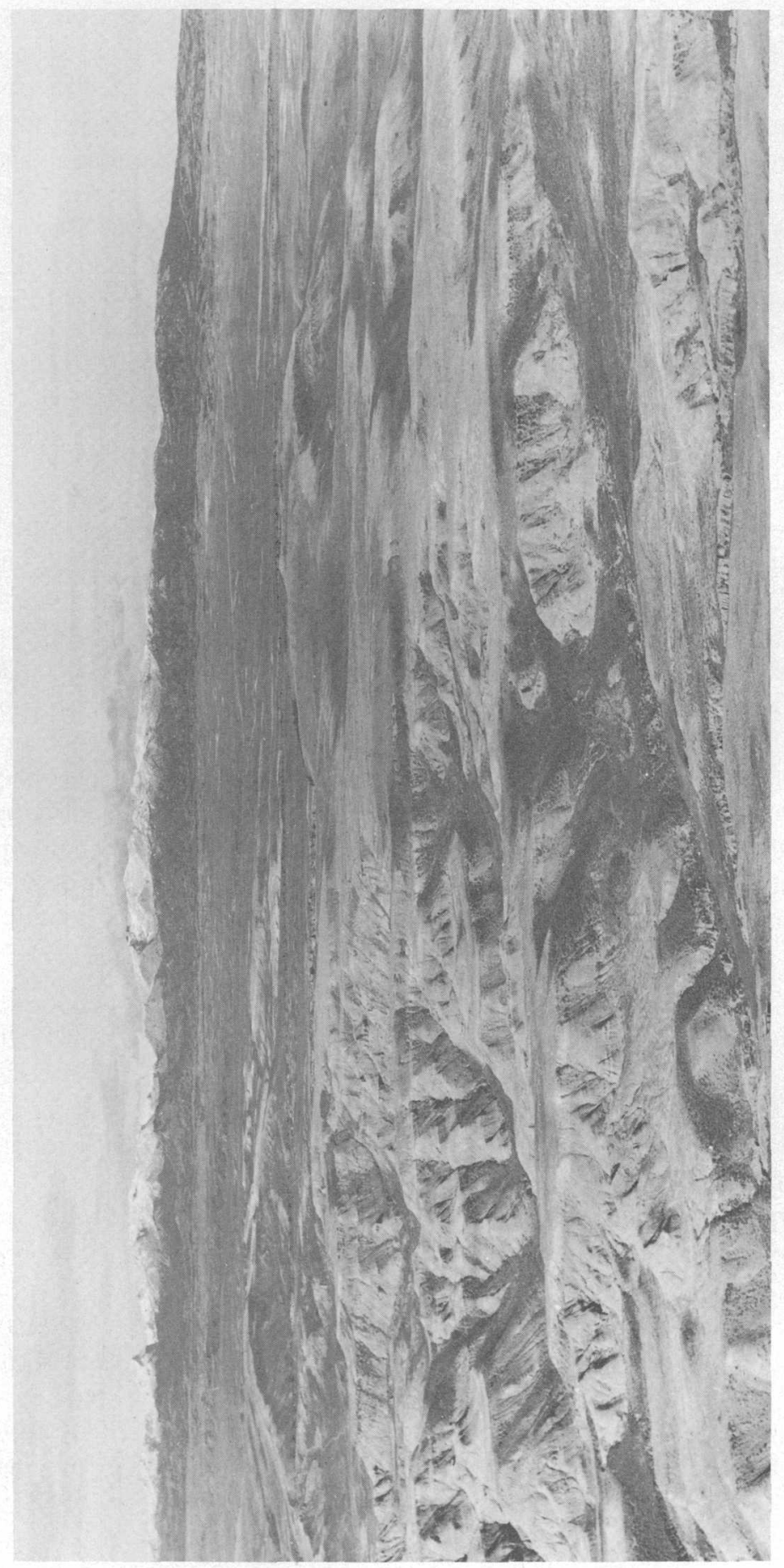

ฐ

क्ष

चี

造

$\stackrel{0}{\circ}$

䑰的

염 흥

을

연

फㅇㅇㅇ

สี

积

표

릉 욜

क.

융

혼

3

잉

과 주

염 엽

so 0

크

응

\%

\pm 궁

ค․ㄹㅇ

모 ี

잉

䓃

몽

出蛋

密 
State Highway 28, which is in the western part of the area, connects Lander, 41 miles to the north, with Farson, 13 miles to the southwest. A network of unimproved dirt roads and wagon trails used by sheepherders crosses the area. Two graded roads, the Middle Hay-Bar X Ranch road from the west and a Bureau of Land Management road from the north, leave State High way 28 and afford access to the Great Divide Basin east of Oregon Buttes and the Joe Hay Rim. The area is accessible by car during the dry summer months of July and August; four-wheel-drive vehicles or trucks with chains are needed during most of the other months. A rail spur connects U.S. Steel's ColumbiaGeneva taconite mill near Atlantic City with the Union Pacific Railroad near Rock Springs, Wyo.

\section{PURPOSE AND SCOPE OF INVESTIGATION}

Detailed geologic mapping in the Oregon Buttes area was done to determine the occurrence and extent of leasable minerals for classification of the public lands. The work included determining the character, thickness, depth, structure, and lithologic variations of mineralbearing stratigraphic units. The map area includes more than 200,000 acres of public land withdrawn pending classification for coal, more than 70,000 acres classified as coal land, 2,500 acres classified as noncoal land, and more than 15,000 acres withdrawn pending classification for oil shale. The results of the geologic mapping described herein form the basis for the classification and restoration of the withdrawn lands. In addition, this investigation will add to the U.S. Geological Survey's geologic atlas of the United States.

\section{LAND SURVEYS AND FIELDWORK}

A cadastral survey of all but one township in the Oregon Buttes area was made in 1882-85 by contractors for the General Land Office. In 1931, the remaining township 26 N., R. 101 W., was surveyed. In 1953, the U.S. Coast and Geodetic Survey ran a first-order level line over South Pass.

The Oregon Buttes area is covered by topographic maps of the U.S. Geological Survey published in 1958 (index on pl. 1). Continental Peak, Dickie Springs, Pacific Springs, Hay Meadow Reservoir, and Parting of the Ways $71 / 2$-minute quadrangles cover the north half of the area; the north half of the 15-minute Essex Mountain and Freighter Gap quadrangles and the northwest quarter of the Pinnacles quadrangle cover the south half of the area. The Lander topographic map of the U.S. Army Map Service includes the map area. 
The geology of the Oregon Buttes was mapped by planetable during the three field seasons of 1961-63 by using topographic base maps (scale $1: 24,000$ ). To map four of the quadrangles, the topographic base was enlarged from 1:62,500 to $1: 24,000$. High-altitude aerial photographs, approximate scale 1:60,000, were used mainly for geologic interpretation.

\section{PREVIOUS INVESTIGATIONS}

The geology of the Oregon Buttes area was first briefly mentioned by Comstock (1874, p. 123-130,146) and later described by Endlich (1879, p. 43-44, 110-114, 128-154) and by Peale (1879, p. 524-526). Schultz (1920, p. 28, pls. 5b and 6c) briefly referred to stratigraphic units in the area. Bradley (1926) discussed the geology of part of the Oregon Buttes area, and the northwest corner of his geologic map $(1926$, p. 130, pl. 63) coincides with the south west corner of the Oregon Buttes map area (pl. 1). Nace (1939) studied and mapped the geology of the northeastern part of the area in detail in 1935, and the northwestern part of the area was covered by a recent geologic map by Berman, Hummel, and McGrew (McGrew and others, 1959). The area is included on a geologic map (scale 1:250,000) by Bradley (1964, pl. 1).

The geologic map $(1: 48,000)$ with this report (pl. 1$)$ is a reduction of $1: 24,000$-scale black and white maps published previously (Zeller and Stephens, 1964a-j).

\section{ACKNOWLEDGMENTS}

The writers thank G. N. Pipiringos for help in clarifying some stratigraphic problems in the Great Divide Basin. N. M. Denson made a valuable contribution with his recognition of a late 'Tertiary stratigraphic unit. G. E. Lewis identified fossils that established definite stratigraphic position for some rock units. J. D. Love, who visited the project in 1962, discussed stratigraphic relations in adjacent areas and pointed out fossil localities. R. L. Bayley, while mapping the area directly to the north, was very helpful in identifying the igneous and metamorphic rocks at the extreme north border of the map. area (pl.1). P. O. McGrew of the University of Wyoming gave the writers a list of fossils collected at several localities in the Oregon Buttes area.

The writers extend most cordial thanks to Mr. Lawrence Hay and his wife Florence and Mr. Leonard Hay of Rock Springs, Wyo., for their hospitality during the summers that they were camped on the Hay's property along the Sweetwater River. Mrs. Hazel Bone and her late husband Elgin at the Middle Hay Ranch also extencled many kindnesses to the writers. 


\section{GEOGRAPHY}

\section{PHYSICAL FEATURES AND DRAINAGE}

The surface of the map area (pl. 1) is dominated by the Oregon Buttes. The buttes are flat topped, rise about 1,500 feet above the plain, and lie near the Fremont and Sweetwater County line (secs. 2, 3, 10, and 11, T. 26 N., R. 101 W.). The southeastern part of the map area is a plain incised by intermittent streams, dotted with sand dunes, and eroded into badlands that characterize the northwestern part of the Great Divide Basin. The maximum relief in the map area, almost 1,900 feet, is from the north butte of the Oregon Buttes $(8,617$ $\mathrm{ft}$ ) to the flat area west of Tule Butte near the southwest corner of the area.

The Sweetwater River, which belongs to the Missouri River watershed, rises in the Wind River Range, flows eastward along the north border of the area (pl. 1) and joins the North Platte River at Pathfinder Reservoir. In the southwestern part of the area, the intermittent creeks-Jack Morrow, Alkali, and Whitehorse-flow westward into Pacific Creek. The Little Sandy, Dry Sandy, and Pacific Creeks flow south into the Big Sandy near Farson, Wyo. The Big Sandy flows into the Green River and makes up part of the Colorado River watershed. A unique phenomenon described by Bradley (1963, p. 26; 1964, p. 7-8) occurs in the map area: the Continental Divide splits at Oregon Buttes (NW1/4 sec. 2, T. 26 N., R. 101 W.; pl. 1), circles the Great Divide Basin, and unites into a single divide 89 miles to the southwest. According to Bradley (1963, p. 26), water that flows into the semiarid Great Divide Basin seemingly evaporates.

\section{VEGETATION AND WILDLIFE}

The principal vegetation in the area is grass and sagebrush. Some greasewood grows in the low flat valleys, and salt sage grows on some flats in the Great Divide Basin. Willows grow along Sweetwater River, Little Sandy Creek, and a few other watercourses. Scrub pine and aspen are scattered along the northward-facing slopes of hills where melting winter snow furnishes ample water into July.

Wild game includes many antelope that range over the entire area, some deer that roam along. Sweetwater River and around Oregon Buttes, a few moose that feed chiefly along Sweetwater River; and sage grouse that are found along Sweetwater River, Little Sandy and Pacific Creeks, and near all reservoirs and springs. Beaver and muskrat live in the Sweetwater River. A herd of more than 20 wild horses inhabits the badland area, called the Honeycombs, just south of Honeycomb Buttes. 


\section{SETTLEMENT AND LAND USE}

No towns or settlements are in the map area. The Middle Hay Ranch, a sheep headquarters, is occupied for all but the coldest months. Other dwellings shown on the map are occupied only during parts of early summer and fall for lambing, docking, shipping of livestock, and hay cutting. The Oregon Buttes area is well known as a source of black petrified wood, and hundreds of collectors visit the area each summer. The land is used chiefly for raising sheep, but some of the grassy bottom lands are used for grazing cattle and horses.

\section{HISTORICAL SKETCH}

Because of the historical significance of the Oregon Buttes area, a brief résumé from the journals of the early travelers and geologists in the area is included. The old Emigrant Trail, which was used by Oregon settlers, Mormons, and California gold seekers, passes through the northern part of the map area. South Pass, which has been aptly called "the pass that built a nation" (Thurman, 1950, p. 14), lies along the Emigrant Trail and is in sec. 4, T. 27 N., R. 101 W., Fremont County (pl. 1). An estimated 300,000 people traveled this trail in the two decades between 1843 and 1863 (Writers' Program, Wyoming, 1941, p. 321).

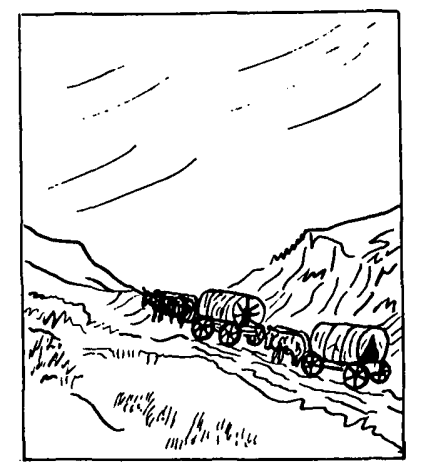

Robert Stuart, who traveled to Oregon in an expedition of the Pacific Fur Co., under Wilson Price Hunt, crossed the north boundary of the present state of Wyoming about August 1, 1811. On Stuart's return to New York from Astoria, Oreg., he and a small party camped near Pacific Springs and then crossed the Continental Divide several miles south of South Pass on October 22, 1812 (Writers' Program, Wyoming, 1941, p. 61-62). In 1824, General William H. Ashley of St. Louis did considerable exploring in the region and named the Sweetwater River. The first wheeled vehicle to cross South Pass was 
said to have been used by an expedition that left St. Louis in March 1827. "It was a rude carriage, on which was mounted a cannon, drawn by a team of mules" (Writers' Program, Wyoming, 1941, p. 63). The pass was crossed July 24,1832 , by Captain B. L. E. Bonneville with a well-organized wagon train party on a secret military mission for the U.S. Government (Irving, 1850, p. 36).

Following the fur trappers came missionaries, and one of the first was the Rev. Samuel Parker who, accompanied by Dr. Marcus Whitman, traveled through South Pass with an expedition of the American Fur Co. in August 1835. The following year Whitman came west again with the Rev. Henry H. Spalding; they were accompanied by their brides, Narcissa Prentiss Whitman and Eliza Hart Spalding, the first white women to make this journey. "The little party reached South Pass on the night of July 3, 1836, and observed the Fourth of July with a fitting ceremony" (Writers' Program, Wyoming, 1941, p. 64-65). A small stone tablet at the pass (sec. 4, T. 27 N., R. 101 W., Fremont County) commemorates this historic occasion.

An excellent review of the early geological explorations in the Green River Basin written by Knight (1955) quotes Rev. Samuel Parker's journal which contains a description of the geography, geology, and climate of the area. Of the Sweetwater valley, Parker wrote: "The geology presents some variety; for while the main ridge of the mountains is gneiss granite, yet to-day parallel ridges of red wacke have abounded. These ridges appear to be volcanic, forced up in dykes, at different distances from each other, running from east north-east to west south-west. The strata are mostly vertical, but some are a little dipped to the south." Knight (1955, p. 12) then questions: "This was written in 1835 by a missionary traveling under the direction of the American Board of Commissioners for Foreign Missions. The writer would like to know where, and under what circumstances the Rev. Parker learned his geology at this early date."

On August 7-9, 1842, John C. Fremont (1845, p. 60), led by Kit Carson, entered this area on a trip to California and briefly described the topography, vegetation, and rock formations of the South Pass area.

Howard Stansbury (1853) journeyed from Fort Leavenworth to Salt Lake City via South Pass in 1849. In his report (p. 71) he describes some of the geology in the map area: "Shortly after passing the summit we found a stratum of apparently metamorphic clay, horizontal, with an east and west direction. Over this were strata of gray sandstone, horizontal, or with a slight dip to the east." This rock outcrop was probably. in the NE1/4 sec. 2, T. 27 N., R. 101 W., and represents the Arikaree Formation of Miocene age. The summit of 
South Pass is so gentle that any place between sec. 4 and sec. 1, T. 27 N., R. 101 W., was considered the pass.

A rock exposure of the Wasatch Formation in sec. 28, T. 27 N., R. 103 W., is described in detail by Stansbury (1853, p. 71): "About a mile from Dry Sandy, some masses of rock were observed on the right of the road, standing up like pillars; they were found to be composed of a coarse sandstone, of an ochrey colour. Under them were white and red shales, apparently horizontal."

J. Goldsborough Bruff of the Washington City and California Gold Mining Association passed through the area with a wagon train August 1, 1849, on the way to the California gold fields. Sketches of "Table Mountain," the present Oregon Buttes, the dividing ridge between the waters of the Pacific and Atlantic Oceans, and an erosional remnant of the Wasatch Formation 2 miles east of the Dry Sandy Creek crossing illustrate this part of his journal (Read and Gaines, 1949, p. 59-64).

In 1856, a Mormon handcart company under the leadership of James G. Willie was caught in a blizzard just northeast of the area along Rock Creek (Driggs, 1942, p. 123). When the party was finally rescued, 100 of the 500 members were dead (Thurman, 1950, p. 15). This occurrence points up a tragic page in Wyoming history and part of the great price that the Mormons paid for religious freedom.

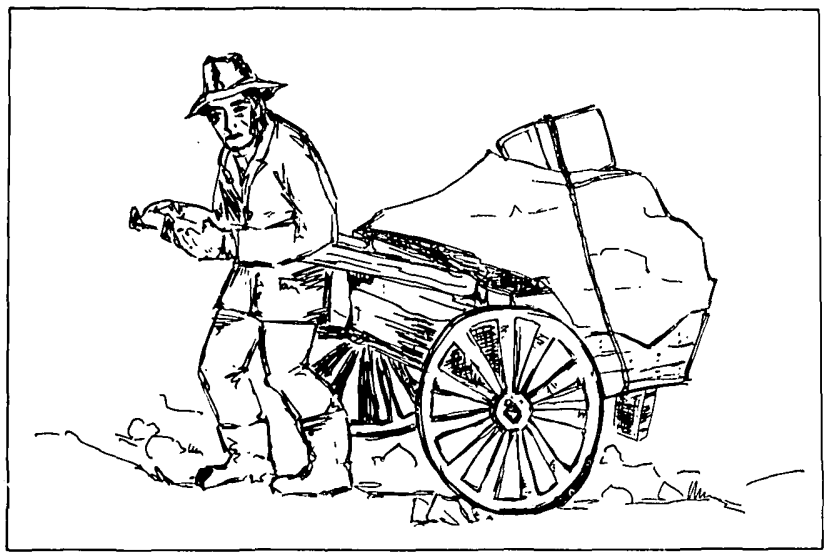

The Emigrant Trail was used also by the Pony Express from April 1860 until November 1861. Two Pony Express Station locations, Pacific Springs (sec. 1, T. 27 N., R. 102 W.) and Dry Sandy (sec. 29, T. 27 N., R. 103 W.), are shown on plate 1. The Upper Sweetwater Station (sec. 16, T. 28 N., R. 100 W.) was on the Sweetwater River just off' the northeast edge of the map area. The Little Sandy Station 
(sec. 28 , T. 26 N., R. 105 W.) was 6 miles southwest of the map area along the Emigrant Trail.

\section{STRATIGRAPHY}

Precambrian rocks in the Oregon Buttes area are represented by metagraywacke intruded by granite and cut by a diabase dike. These rocks are exposed only in patches along the extreme north edge of the map area (pl. 1). The sedimentary rocks exposed in the Oregon Buttes area consist of lacustrine and fluviatile deposits which total about 2,000 feet in thickness and range in age from early Eocene to Pliocene (table 1). Unexposed rocks include about 25,000 feet of sedimentary rocks which range in age from Paleocene to Cambrian overlying the crystalline Precambrian basement.

Rocks underlying the area which do not crop out range in age from Cambrian to Paleocene and have a total thickness of 20,000-25,000 feet. The Superior Oil Co. Pacific Creek Unit 1 Govt. in the SWI/4 sec. 27, T. 27 N., R. 103 W., abandoned in 1949, was drilled to a total depth of 20,521 feet (at the time the world's deepest well) and was reported to have bottomed near the base of the Upper 'Cretaceous Frontier Formation. The thickness of the sedimentary section between the Frontier Formation and Precambrian basement rocks is not precisely known, but it has been estimated (Jenkins, 1955a, p. 154) to be 6,000 feet or more. Berg (1962, p. 2022), using seismic methods, estimated a total of 30,000 feet of sedimentary rocks above the Precambrian basement along the southwest flank of the Wind River Range. The identification of formation boundaries in the log of the Superior well varies from interpreter to interpreter. The writers, however, have selected the following intervals as being most nearly correct:

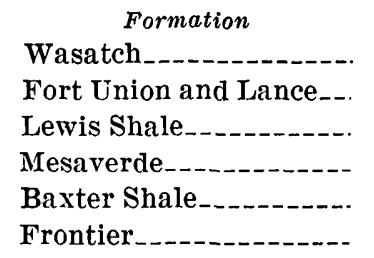

\section{PRECAMBRIAN ROCKS}

Discontinuous exposures of Precambrian rocks extend along the north margin of the map area from sec. 30, T. 28 N., R. 101 W., eastward for about 10 miles. The rocks consist of dark-gray slabby metagraywacke intruded by granite and a diabase dike. The metagraywacke strikes east and dips $30^{\circ}-40^{\circ} \mathrm{N}$. The pinkish-gray granite is generally coarse grained to pegmatitic and contains microcline, quartz, and mica. 


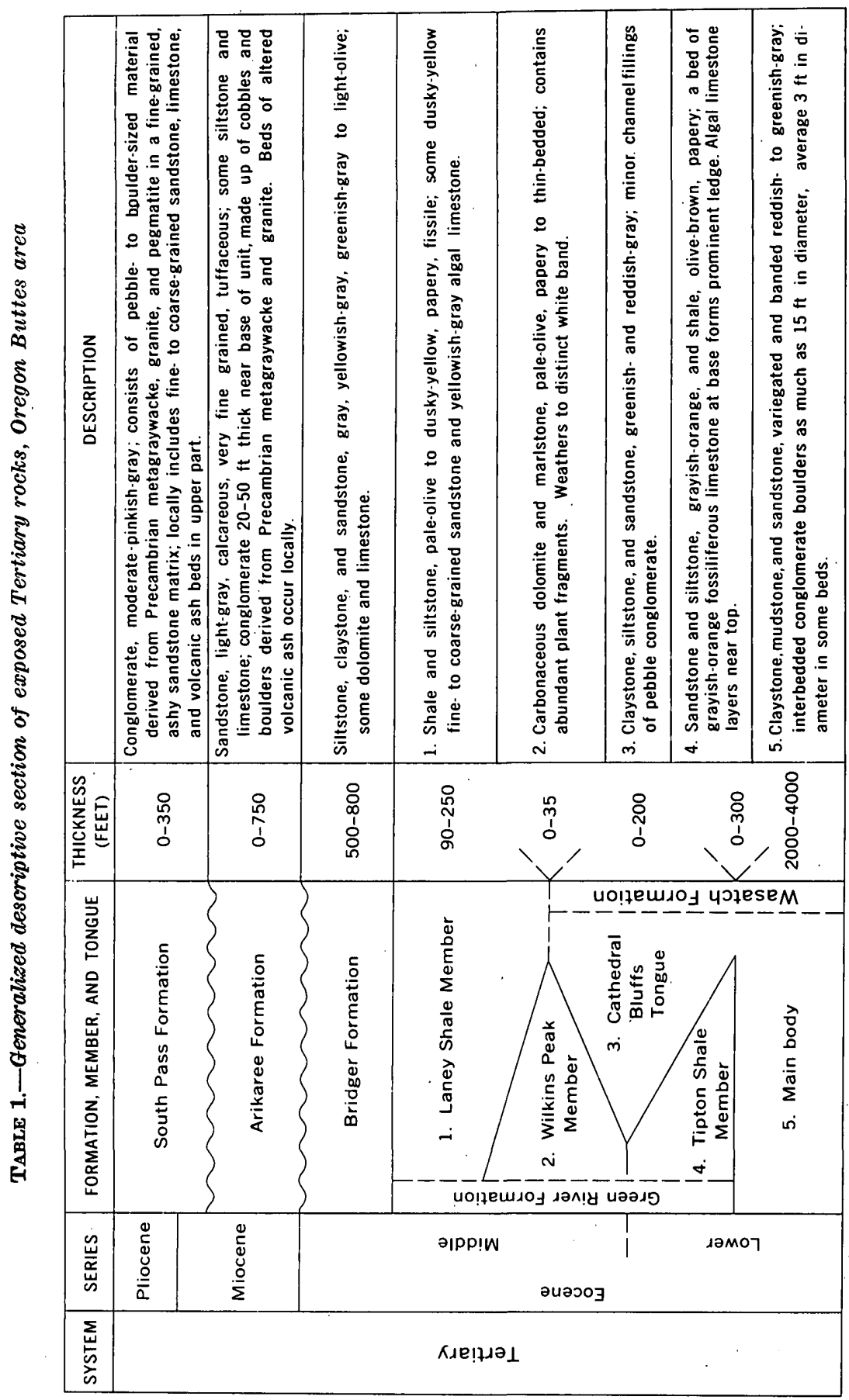


The diabase dike trends east-northeast and is about 100 feet thick; the rock is very dark gray to black and contains lath-shaped feldspar phenocrysts. Graded bedding, useful for determining tops of beds, is reported in the metagraywacke north of the area (Bayley, 1965a, b).

\section{TERTIARY ROCKS}

\section{WASATCH AND GREEN RIVER FORMATION}

In the map area the Wasatch Formation of early and middle Eocene age, approximately 3,200 feet thick, consists predominantly of fluviatile green and red variegated mudstone containing scattered sand grains and quartz and chert granules and pebbles, lenticular duskyyellow fine-grained to very coarse grained sandstone, and minor coal and algal limestone. The Green River Formation of early and middle Eocene age consists of approximately 450 feet of lacustrine moderateyellowish-brown and dusky-yellowish-green paper shale, marlstone, fine- to coarse-grained sandstone, and algal limestone. The two formations intertongue, and five members are recognizable in the map area; they are, in ascending order, the main body of the Wasatch Formation, the Tipton Shale Member of the Green River Formation, the Cathedral Bluffs Tongue of the Wasatch Formation, and the Wilkins Peak and Laney Shale Members of the Green River Formation (fig. 3; plate 2 ; table 1).

\section{MAIN BODY OF THE WASATCH FORMATION}

The main body of the Wasatch Formation of early Eocene age in the Oregon Buttes area is exposed in sec. 21, T. 25 N., R. 102 W., near the center of the south margin of the map area. The main body is characterized by pastel red and purple claystone and mudstone and thick lenticular dusky-yellow coarse-grained sandstone. Sandstone and arkose dominate the lithology north of sec. 21. The sample log of the Superior Oil Co. Pacific Creek Unit 1 Govt. well in sec. 27, T. 27 N., R. $103 \mathrm{~W}$., indicates continuous sandstone and arkose between depths of 1,000 and 2,950 feet and only minor sandy shale between 2,950 and 3,590 feet. The average thickness of the Wasatch Formation in oil-test holes drilled south of the map area is a little more than 3,000 feet.

TIPTON SHALE MEMBER OF THE GREEN RIVER FORMATION

The Tipton Shale Member of the Green River Formation of early Eocene age in the Oregon Buttes area consists of interbedded paper shale, limestone, mudstone, and arkosic sandstone. A stratigraphic section measured in the NE1/4 sec. 22 , T. 25 N., R. 103 W., shows the Tipton to consist of interbedded fossiliferous limestone, grayish-green mudstone and siltstone, moderate-grayish-orange fine- to medium- 


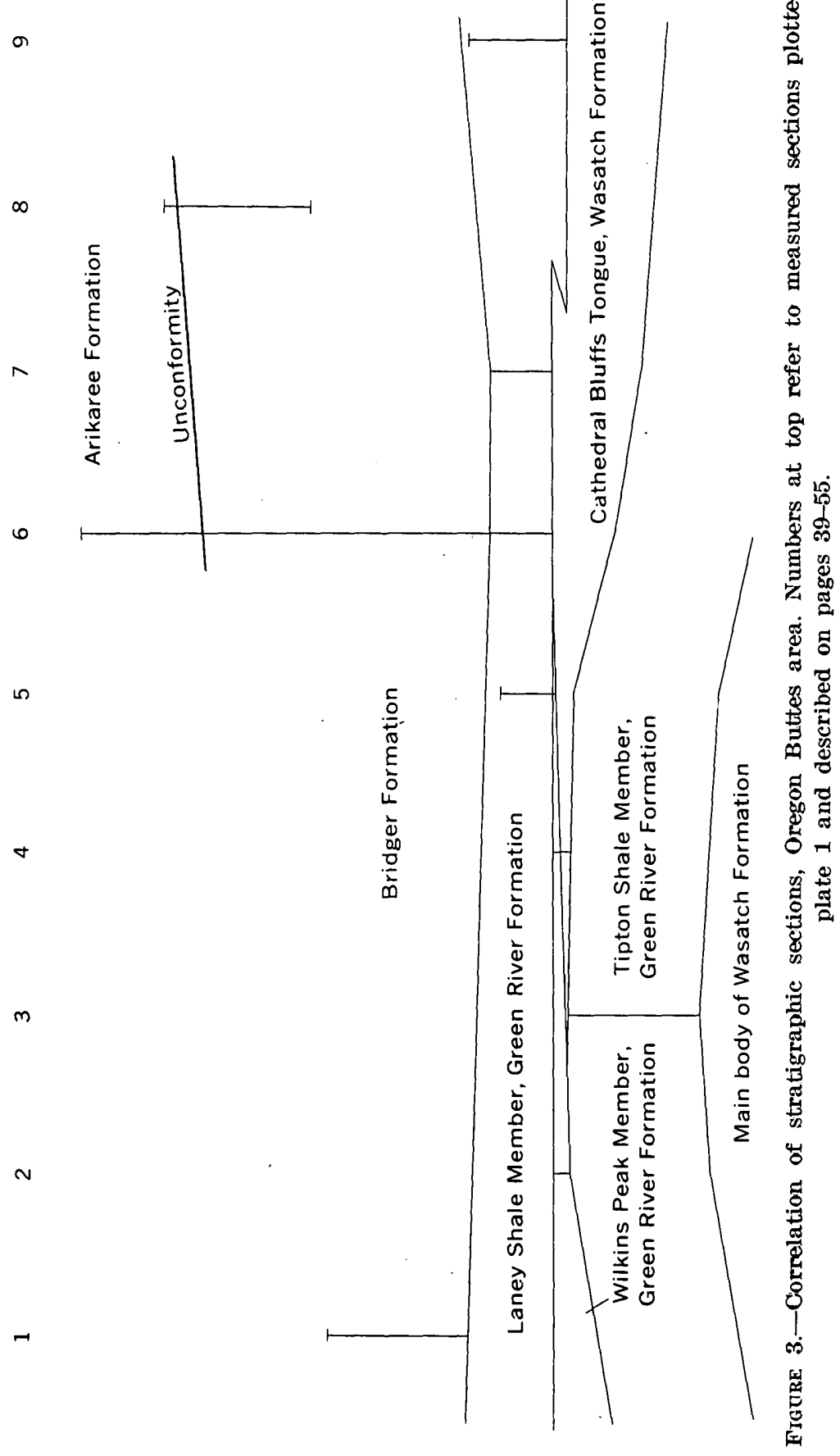

$311-9410-69-3$ 
grained massive to crossbedded arkosic sandstone, and light-yellowishgray algal limestone (fig. 3; strat. sec. 3, p. 40).

The Tipton Shale Member is divisible into two parts in the Oregon Buttes area, as it is at Tipton (Schultz, 1920) and in the Great Divide Basin (Pipiringos, 1961). In these areas the total thickness of the member is about the same; however, the thickness of the two parts varies greatly. The lower part is about 60 feet thick in the southwestern part of the Oregon Buttes area (strat. sec. 3, p. 41), but thickens to about 160 feet in the Great Divide Basin and Wamsutter arch areas (Pipiringos, 1961). The upper part is about 240 feet thick in the Oregon Buttes area and about 120 feet near Red Desert. The lower part is composed chiefly of fossiliferous limestone and paper shale, and the upper part is composed chiefly of green mudstone, arkosic sandstone, and algal balls.

A persistent basal bed of fossiliferous limestone and sandstone rests conformably on the main body of the Wasatch Formation. Abundant shells of Goniobasis are characteristic of this bed, and in this report, it is called, therefore, the Goniobasis bed.

Algal balls are characteristic of the upper part of the Tipton near Oregon Buttes and in the Red Desert (Pipiringos, 1961, p. 29). The highest persistent bed of algal balls was chosen by the writers to be the top of the Tipton; this bed is easily recognized and has been mapped in the study area. Its selection produces a different Tipton outcrop pattern (pl. 1) than is shown on Bradley's maps (1926, pl. $58 ; 1961)$. Schultz (1920, p. $59 ;$ pl. 1, sec. 5) published a section of the Tipton measured on a hill in sec. 18, T. 24 N., R. 103 W., just south of the map area, and Bradley $(1926$, p. $130 ;$ pl. 58, loc. 5) published a section measured on the same hill. Schultz included all exposed rocks in the Tipton; Bradley, however, picked the top of the Tipton about 25 feet below the top of the hill, as he apparently believed that the green claystone and sandstone which enclose the algal-ball zones are more typical of the overlying Cathedral Bluffs Tongue of the fluviatile Wasatch Formation than of the lacustrine Tipton Shale Member.

The nearshore lacustrine deposits of the Tipton Shale Member grade into fluviatile deposits of the Wasatch northward, and so the Tipton is present only in the southernmost part of the map area. Nace (1939, p. 15-16) considered a massive sandstone body in the Wasatch Formation exposed at Reds Cabin monocline, sec. 21, T. 27 N., R. 101 W. (pl. 1), to be a nearshore equivalent to the Tipton. A 10-mile gap separates Tipton outcrops exposed near Rock Cabin Creek and outcrops in the monocline. Similar sandstone bodies are a characteristic constituent of the Wasatch Formation, however, and the only fossils described from the monocline were land snails referred to Viviparus 
paludinaeiformis (Hall)? (Nace, 1939, p. 16). Because of difficulty in distinguishing Tipton from Wasatch sandstone beds and because no conclusive evidence was found to indicate that the well-exposed sandstone at the monocline is in the Green River Formation, the Tipton Shale Member is not considered to extend north of T. 26.

The early Eocene age of the Tipton Shale Member is well established by fossils in the Oregon Buttes area. Bradley (1926, p. 130) found Parameryx in a pebbly sandstone beach deposit containing fish bones at his locality 3 in the NE1/4 sec. 25, T. 25 N., R. 102 W. At the same locality, P. O. McGrew (written commun., 1964) found Lambdotherium, a genus diagnostic of the Lost Cabin faunal zone (uppermost lower Eocene) (Wood and others, 1941). In the northwest quarter of the same section, McGrew (written commun., 1964) found Hyracotherium, diagnostic of early Eocene age, in the Goniobasis bed.

\section{CATHEDRAL BLUFFS TONGUE OF THE WASATCH FORMATION}

The Cathedral Bluffs Tongue of the Wasatch Formation of early and middle Eocene age in the map area consists of interbedded variegated red and green arenaceous and conglomeratic mudstone, fine-grained to very coarse grained sandstone, and a few beds of algal limestone. The tongue averages 160 feet in thickness and crops out in the southeastern part of the map area along the northwest margin of the Great Divide Basin (fig. 4). Shades of green characterize the upper half of the unit, and shades of red characterize the lower half. The Cathedral

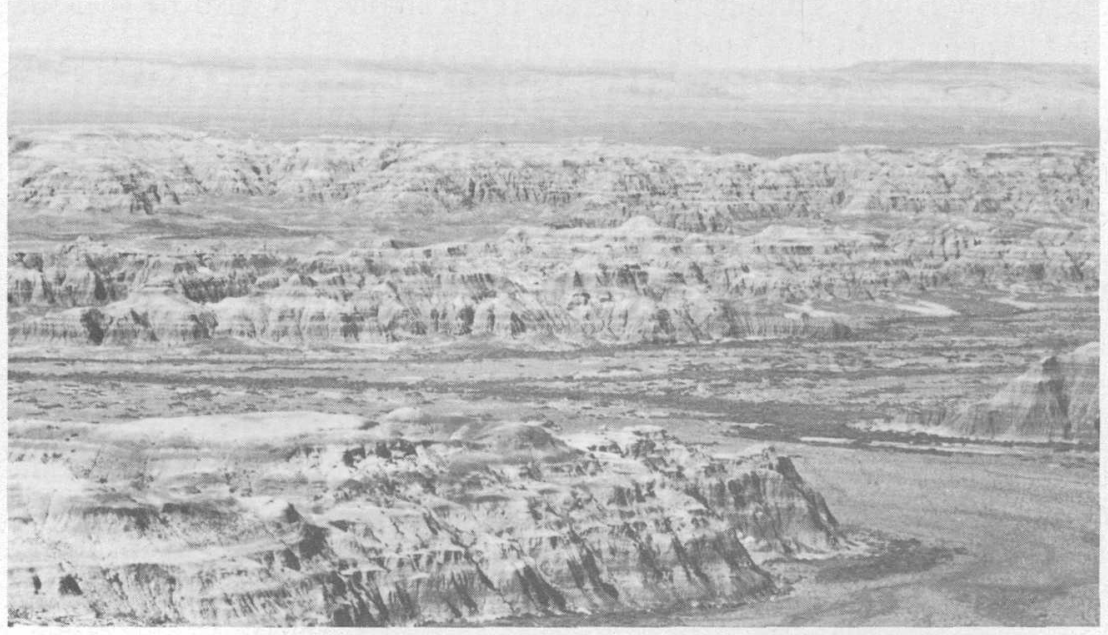

Frgure 4.-View looking west at Cathedral Bluffs Tongue of the Wasatch Formation (T. 26 N., R. 99 W.). Typical erosional remnants southwest of Honeycomb Buttes. 
Bluffs, locally as much as 200 feet thick. thins southward and westward and pinches out just north of Jack Morrow Creek in sec. 18, T. 25 N., K. 103 W. (fig. 3). Green mudstone in the upper half of the unit intertongues with tan paper shale of the Laney Shale Member of the Green River Formation in the SW1/4 sec. 27, T. 27 N., R. 100 W., and near the head of Sand Creek northeast of Continental Peak (sec. 25, T. 27 N., R. 100 W.). North of the outcropping belt of the Laney (pl. 1), rocks equivalent to the Cathedral Bluffs Tongue were mapped as Wasatch Formation undivided because no rocks belonging to the Tipton Shale Member of the Green River Formation were identified. Where the Tipton is absent the Wasatch Formation cannot be divided.

North of Oregon Buttes the upper part of the Wasatch Formation undivided (Cathedral Bluffs Tongue) contains more sandstone, arkose, and conglomerate than in the south. Boulders as much as 15 feet in diameter, weathered from this upper part, are exposed along the Continental fault in T. 27 N., Rs. 100-103 W. The Sinclair Oil Co. Oregon Trail Unit 1 Govt. well, drilled in the NW1/4 sec. 24, T. 27 N., R. 101 W., penetrated more than 1,100 feet of coarse arkose above Precambrian basement rocks. Near the middle of the map area, the upper part of the Wasatch Formation undivided (Cathedral Bluffs Tongue) contains scattered algal reefs. One of the reefs is exposed on the north side of the isolated butte in the SW1/4 sec. 30, T. 27 N., R. 101 W., and a larger reef is exposed near the head of Alkali Wash in the NE1/4 sec. 24, T. 26 N., R. 102 W. In the southwestern part of T. 26 N., R. 102 W., algal layers are persistent and mark the top of the Cathedral Bluffs Tongue. Scattered algal bodies can also be seen in the Cathedral Bluffs Tongue in T. 26 N., R. 99 W.

Fossils are rare in the Cathedral Bluffs Tongue, and paleontologists disagree on the age of the fauna that has been collected. Morris (1954, p. 197) collected and studied fossils from near the type locality of the Cathedral Bluffs and concluded that the specimens were of early middle Eocene age. Gazin $(1959$, p. 135) re-examined Morris' collection and some additional specimens and assigned an early Eocene age to the collection. A difference of opinion arose concerning the age of a single tooth that Nace $(1939, \mathrm{p} .17)$ found in the Cathedral Bluffs Tongue in T. 26 N., R. 98 W. G. G. Simpson (Nace, 1939 , p. 26-27) offered the opinion that the tooth was probably from Tillotherium and indicated a middle Eocene age. This tooth has been re-examined and is now considered to be from Trogosus sp., which has been found in both uppermost lower Eocene and lowermost middle Eocene rocks (Peter Robinson, written commun., 1964). Gazin (1962, p. 20) collected several additional specimens from the Cathedral Bluffs southwest of Continental Peak and northwest of Oregon 
Buttes and stated: "These few specimens give no clue as to whether the age represented is that of the Lost Cabin or Bridger beds." A rodent fauna collected by P. O. McGrew in sec. 25, T. 25 N., R. 102 W., from the Cathedral Bluffs Tongue was examined by A. E. Wood (written commun. to McGrew, 1957), who reported that the material could not be earlier than type Lost Cabin (latest early Eocene) nor later than Bridger.

Gazin (1962, p. 20) speculated that the change from red to green sediments in the Cathedral Bluffs in the Oregon Buttes area "represents the transition from Cathedral Bluffs to Bridger." The exact position of the time boundary may not be so easily placed, however. Diagnostic faunas of early Eocene age have been collected from the Cathedral Bluffs (Gazin, 1959, p. 135), but the upper green mudstones intertongue with beds of the Laney Shale Member of the Green River Formation considered to be of middle Eocene age. These facts, together with the transitional age of the fossils in the area, suggest that part of the Cathedral Bluffs Tongue was deposited during early Eocene time and part during middle Eocene time. The age of the Cathedral Bluffs Tongue in the Oregon Buttes area is, therefore, considered to be early and middle Eocene.

\section{WILKINS PEAK MEMBER OF THE GREEN RIVER FORMATION}

The Wilkins Peak Member of the Green River Formation of middle Eocene age in the Oregon Buttes area consists of about 35 feet of greenish-brown and grayish-green claystone, oil shale, and marlstone. Near the southwestern part of the area, these rocks (strat. sec. 2, p. 40 ; fig. 3 ) crop out in a striking white-weathering band, devoid of vegetation, which crosses Jack Morrow Creek in sec. 18, T. 25 N., R. $103 \mathrm{~W}$. (pl. 1). In other parts of the area, the Wilkins Peak is poorly exposed. These rocks are considered to have been deposited in Gosiute Lake (Bradley, 1929b, p. 88).

The member thins northward and thickens abruptly southward (fig. 3). It is 20 feet thick just north of Jack Morrow Creek, is 15 feet thick in South Packsaddle Canyon, and pinches out south of the north edge of the outcrop belt of the Laney Shale Member and west of sec. 20, T. 25 N., R. 101 W. Bradley (1961) reported that the Wilkins Peak reaches a maximum thickness of 1,350 feet in the Green River Basin (fig. 1).

No fossils diagnostic of age have been found in the Wilkins Peak Member and, accordingly, its age is not directly known. At its wedge edge the member grades into the Laney Shale Member, which has yielded large collections of Eocene vertebrates (Bradley, 1964, p. 45-46). The Wilkins Peak Member is, therefore, considered to be of middle Eocene age. 
LANEY SHALE MEMBER OF THE GREEN RIVER FORMATION

The Laney Shale Member of the Green River Formation of middle Eocene age in the Oregon Buttes area is exposed in an unbroken belt extending generally east-west across the central part of the map area (pl. 1). The Laney consists of beds of paper shale, limestone, siltstone, and fine-grained sandstone. The paper shale is generally dusky yellow to grayish olive and contains thin altered volcanic-ash layers; the limestone contains abundant ostracodes and algal structures; the sandstone is very fine grained to coarse grained and contains abundant biotite, clayey siltstone, and platy siliceous dolomite (strat. sections 5-7, 9-10, p. 43-47, 48-51). The total amount of sandstone in the sequences increases northward. The Laney is considered to have been deposited in Gosiute Lake (Bradley, 1929b, p. 88).

The member is thinnest in sec. 22, T. 27 N., R. 101 W. (strat. section 10, p. 50) and thickens southward, eastward, and westward. It is about 150 feet thick at the Oregon Buttes in T. 26 N., R. 101 W. (strat. section 6 , p. 46 ; fig. 3 ) where the top is marked by a silicified algal limestone bed that forms extensive flats. The Laney is about 200 feet thick near Tule Butte, T. 25 N., R. 104 W., and thickens westward into the Green River Basin. The member thickens toward the Great Divide Basin and is more than 225 feet thick in the Honeycomb Buttes in $\mathbf{T}$. 26 N., R. 99 W. (strat. section 9, p. 48; fig. 3).

In the eastern part of the map area, the top of the member is marked by a series of light-yellowish-gray platy siliceous dolomite beds that cap the higher hills; in the western part of the map area, the top of the member is also marked by platy dolomite beds that tend to form flat areas near Tule Butte. The member overlies and intertongues with the Wilkins Peak Member of the Green River Formation in the southwestern part of the map area, conformably overlies the Cathedral Bluffs Tongue of the Wasatch Formation and equivalent rocks (upper part of the Wasatch Formation undivided) in the central part of the area, and overlies and intertongues with the Cathedral Bluffs Tongue and equivalent rocks in the east-central part of the area. The Laney contains many vertebrate fossils of middle Eocene age (Bradley, 1964, p. $45-46)$.

\section{BRIDGER FORMATION}

The Bridger Formation (Hayden, 1869, p. 191) of middle Eocene age in the Oregon Buttes area consists of interbedded sandstone, siltstone, and claystone. As much as 800 feet of light-gray and light-grayish-orange fluviatile sandstone, siltstone, and claystone, lacustrine algal limestone, and thin-bedded marlstone is exposed at Continental Peak (strat. sec. 8, p. 48), Oregon Buttes (strat. sec. 6, p. 43; fig. 3), Joe Hay Rim, Tule Butte (strat. section 1, p. 39; fig. 3), and along the north side of the Continental fault. 
Two persistent lacustrine beds were mapped in the Bridger for stratigraphic control. An algal bed, averaging 2 feet in thickness is limestone about 175 feet above the base of the Bridger and is characterized by the presence of upright petrified tree stumps, many of which are covered by algal layers (fig. 5 ). A dolomite bed, about 15 feet thick, is a thin-bedded fossiliferous marlstone about 300 feet above the base of the formation that tends to weather into two distinct ledges.

The age of the Bridger Formation in the area is well substantiated by the presence of two key fossils. From fossil locality D563 (SW1/4 sec. 15, T. 25 N., R. 104 W., Sweetwater County) on the northwest side of Tule Butte, 200 feet above the base of the Bridger, G. E. Lewis (written commun., 1963) identified a fragmentary right ramus of Smilodectes gracilis (Marsh) and teeth fragments from Hyrachyus sp. of middle Eocene age, typical of the Bridger Formation and probably from the lower part of the formation. G. E. Lewis (written commun., 1963) identified a fragmentary left ramus from locality D564 (SE1/4 sec. 35, T. 27 N., R. 100 W., Fremont County) as an immature specimen of Orohippus vintanus (Marsh) of middle Eocene age, typical of the upper part of the Bridger Formation.

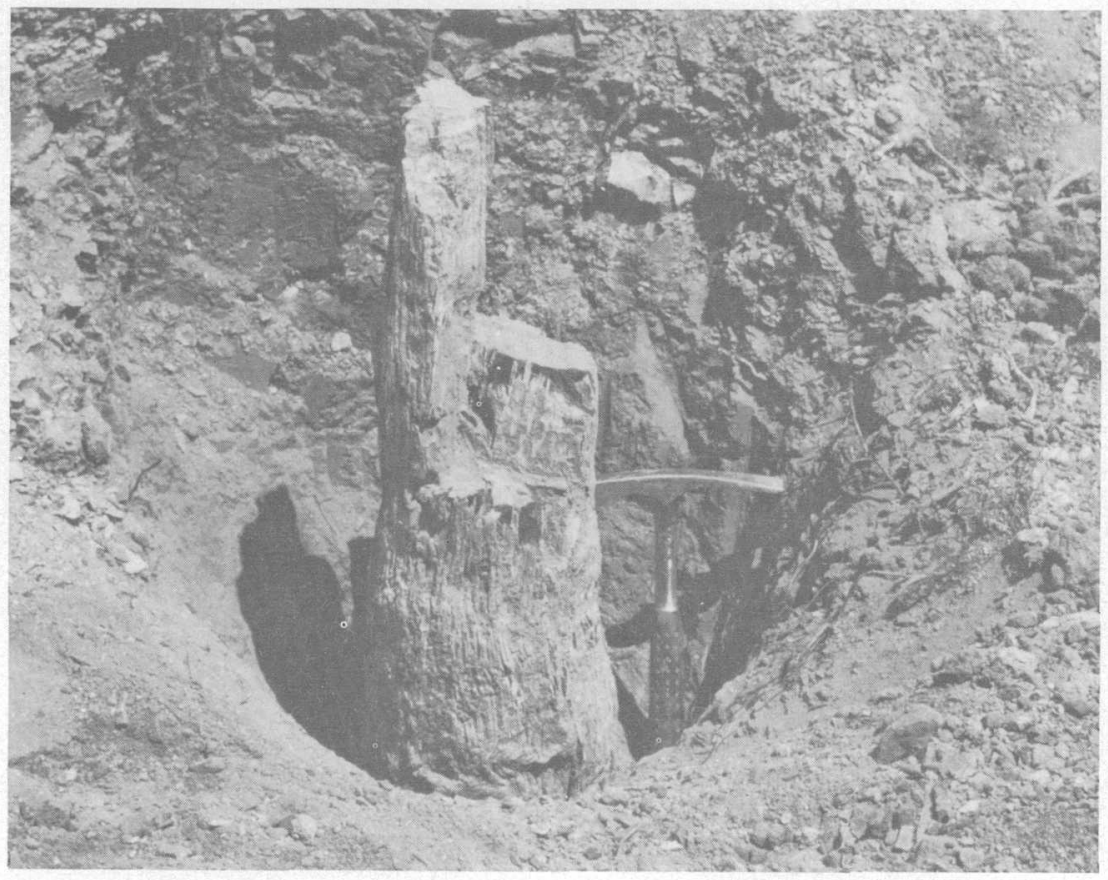

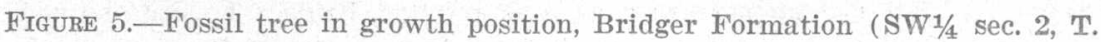
26 N., R. 101 W.). 
Locality D564 is of particular interest because it is on the northeast slope of Continental Peak, 65 feet below the summit and 45 feet below the top of the type section of the Continental Peak Formation of Nace (1939, p. 11, 21-25, 31, 42, pl. 1). Nace believed that the Continental Peak Formation correlated with either the upper part of the Bridger Formation or with the Uinta Formation, but lacking diagnostic vertebrate fossils at that time, he "believed that application of either name, Bridger or Uinta, to these beds might lead to further confusion of terminology $* * *$. The name, Continental Peak Formation, is therefore used as a tentative designation pending discovery of paleontologic data" (Nace, 1939, p. 31). For this reason, Nace (1939, p. 11, pl. 1) showed the Continental Peak Formation as upper(?) Eocene.

P. O. McGrew (written commun., 1963) found Washakius ef. insignis (Univ. of Wyoming, Nos. 1319, 1648), also typical of the middle Eocene Bridger Formation, at a small butte (SE1/4 sec. 34, T. 27 N., R. 101 W.) just north of Oregon Buttes.

\section{ARIKAREE FORMATION}

The Arikaree Formation of Miocene age overlies the Bridger Formation in the Oregon Buttes area and consists of light-gray calcareous very fine grained tuffaceous sandstone and siltstone as much as 750 feet thick. A basal conglomerate $20-50$ feet thick is composed of material derived from local Precambrian rocks (figs. 3, 6, 7; strat. section

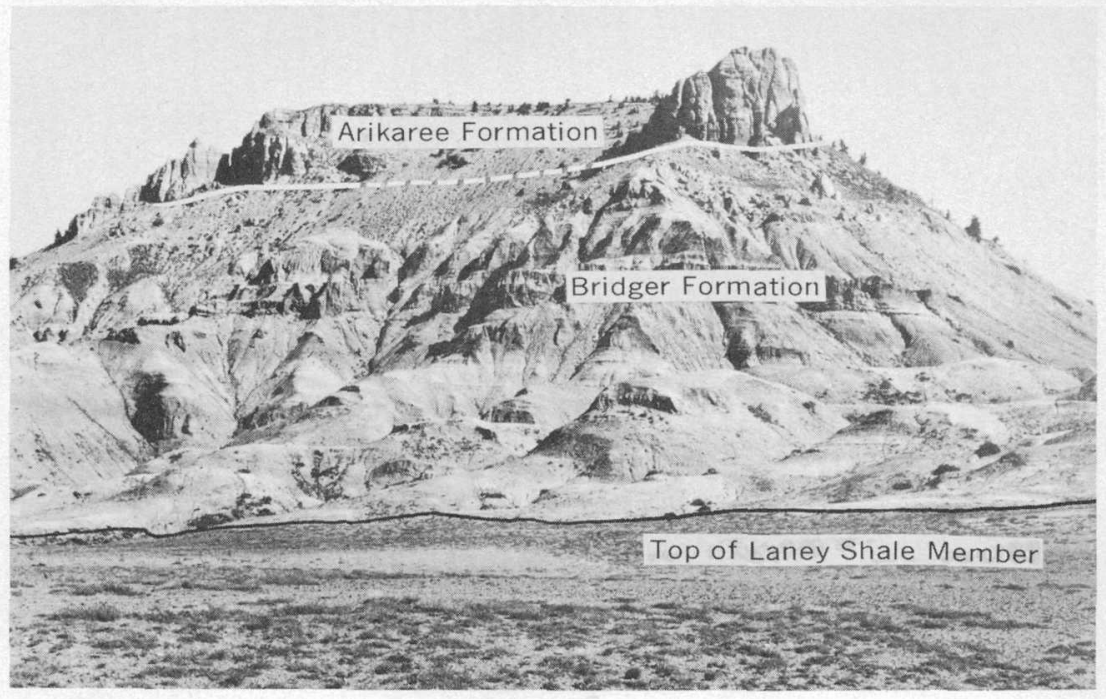

FIGURE 6.-View looking northwest at Arikaree and Bridger Formations and Laney Shale Member of Green River Formation on Oregon Buttes (SW1/4 sec. 11, T. 26 N., R. 101 W.). (See strat. section 6, pl. 1; fig. 3). 


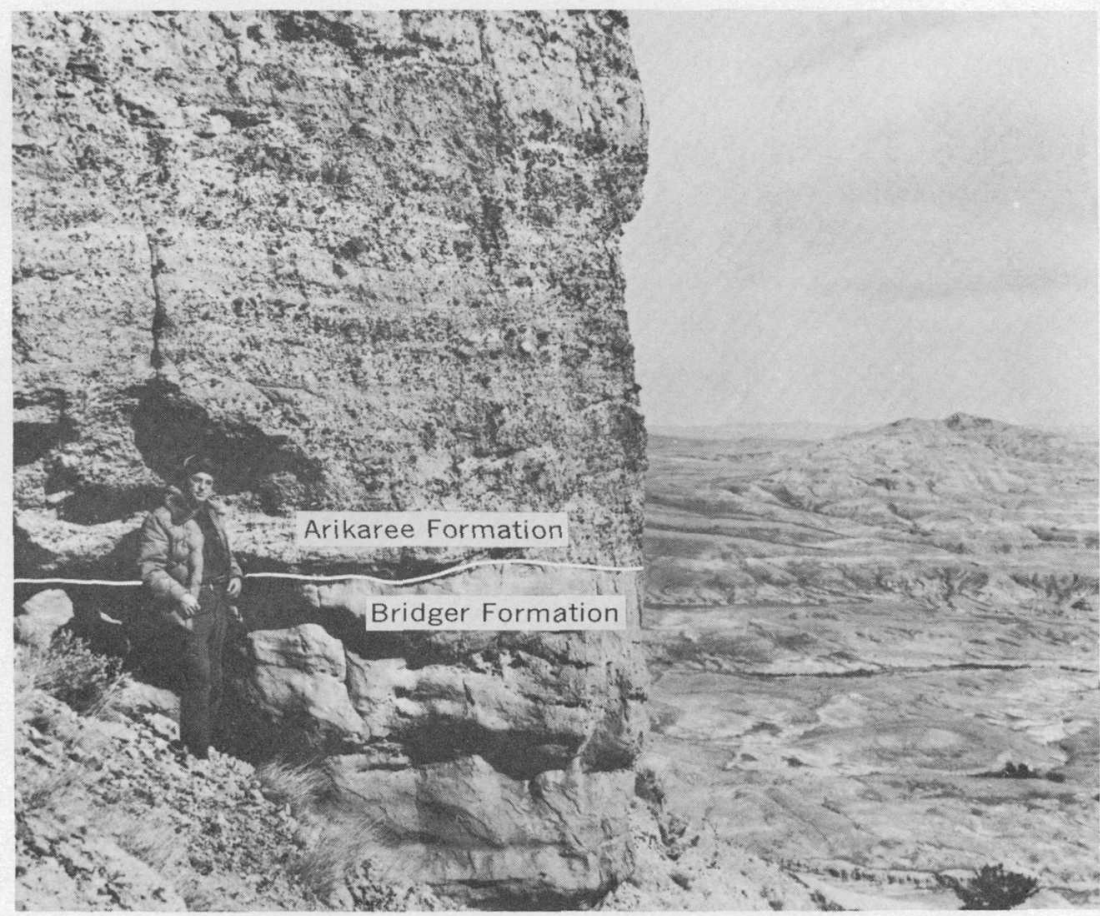

Figure 7.-Basal conglomerate of the Arikaree Formation, resting unconformably on the Bridger Formation at Oregon Buttes (NE1/4 sec. 3, T. 26 N., R. 101 W.). East view; Continental Peak is in background. Photograph by N. M. Denson.

$6, p .43)$. The formation crops out north of the Continental fault and caps Oregon Buttes; about 20 feet of the basal conglomerate caps Continental Peak (Denson and others, 1965). Beds of altered volcanic ash occur at different horizons, and several silicified zones contain manganese dendrites which could be the source of some of the "Sweetwater moss agates" found in the basal conglomerate of the overlying. South Pass Formation.

The rocks above the Bridger Formation are here assigned for the first time to the Arikaree Formation. Previously, the formation was shown as the "Beaver Divide conglomerate and 'Upper' Chadron members" of the Chadron Formation (Nace, 1939, p. 11). Love, Weitz, and Hose (1955) showed the Oregon Buttes capped with White River Formation, but they mapped the area north of the Continental fault as undivided Miocene and Oligocene rocks. There are no Oligocene rocks north of the Continental fault in the map area.

$311-9410-69-4$ 
The formation weathers lighter gray on the north side of the Continental fault than on Oregon Buttes, whereas the Arikaree Formation on Oregon Buttes is better cemented with calcium carbonate than the rocks north of the fault. These differences in color and cement led some geologists to believe that the rocks north of the fault differ from those in the section exposed on Oregon Buttes (P. O. McGrew, oral commun., 1962 ; J. D. Love, oral commun., 1962). The writers are convinced, however, because of the similarity of the entire sequence and their examination of many individual beds both on Oregon Buttes and north of the fault, that a single formation, the Arikaree, is present at both places.

The writers and J. D. Love collected fossils from a tuffaceous sandstone in the Arikaree Formation exposed 5 miles east of the map area and a mile west of Circle Bar Lake along the north side of the Continental fault (SW1/4 sec. 28, T. 27 N., R. 98 W., Fremont County). F. C. Whitmore, Jr., (written commun., 1963) identified these fossils as mainly fragmentary bones of Artiodactyla. He states: "The size of the larger camel in the collection is of some stratigraphic help, as there were no camels of this size earlier than Arikaree time. You can therefore safely say that these rocks are Miocene or younger." Love (1961, p. 11) has shown that, farther east, equivalent rocks called the Split Rock Formation (name now abandoned by the U.S. Geol. Survey; Denson, 1965) are of early and middle Miocene age.

\section{SOUTH PASS FORMATION}

The South Pass Formation of late Miocene to middle Pliocene age in the Oregon Buttes area is composed of a conglomeratic sequence of sandstone, limestone, and volcanic ash. The formation has a maximum thiokness of about 350 feet (Denson and others, 1965). The formation unconformably overlies the Arikaree Formation, the Bridger Formation, and Precambrian rocks and is overlain by pediment gravel and alluvium of Quaternary age.

The formation is composed dominantly of pinkish-gray. pebble to boulder conglomerate in a matrix of fine-grained tuffaceous sandstone and siltstone. Locally, the conglomerate contains pebbles of moss agate, and the agates are abundant on the surface in secs. 32 and 33 , T. 28 N., R. 103 W. These agates are identical with the "Sweetwater agates" from the Granite Mountains area described by Love (1961, p. 14). Most agates are translucent gray with black manganese dendrites, although some are red or brown. They fluoresce a pale yellow green under ultraviolet light. Locally, the conglomerate is interbedded with very coarse grained arkosic sandstone and is overlain by fineto coarse-grained laminated strongly fluorescent sandstone which has a maximum thickness of 200 feet and volcanic ash which has a maxi- 
mum thickness of 15 feet. The thickness of the formation in the map area ranges from 0 feet to about 350 feet. More than 100 feet of the formation is exposed along many northward-facing escarpments on the south side of Sweetwater River (secs. 25, 26, and 35, T. 28 N., R. 101 W.; secs. $25,26,27$, and 30, T. 28 N., R. 100 W.). Here, the formation is heterogeneous and includes boulders and cobbles of Precambrian metamorphic and igneous rocks in a matrix of fine-grained tuffaceous siltstone derived from the White River Formation (Oligocene) and tuffaceous sandstone derived from the Arikaree Formation (Miocene).

The South Pass overlies the Arikaree in secs. 27 and 30, T. 28 N., R. 102 W.; it overlies the Bridger in secs. 27 and $28,{ }^{\prime}$ T. 28 N., R. 104 W., secs. 29, 30, 31, 32, and 33, T. 28 N., R. 103 W., and secs. 3 and 4, T. 27 N., R. 103 W.; and it overlies Precambrian rocks in secs. 28, 29, and 30, T. 28 N., R. 100 W., and secs. 28, 29, and 30, T. 28 N., R. 101 W. Northwest of the map area in T. 30 N., R.104 W., and along the northeast flank of the Wind River Range in Tps. 29 and 30 N., Rs. 98 and $99 \mathrm{~W}$., the formation rests on the beveled edge of as much as 800 feet of White River Formation. The South Pass Formation fills preexisting valleys and forms pediment and coalescing alluvial fanlike deposits along both flanks at the south end of the Wind River Range. The heterogeneity of the rocks and the rapid changes in lithology along the outcrop are distinguishing characteristics of the unit and probably represent torrential short-duration deposition following major uplift of the Wind River Range at the end of Miocene time. The rocks herein assigned to the South Pass Formation have been designated as "post-Bridgerian" by McGrew and others $(1959$, fig. 1), as the basal part of the White River Formation (Beaver Divide Conglomerate Member) by Nace $(1939, \mathrm{pl} .1)$, and as middle and upper Eocene by Love, Weitz, and Hose (1955).

The exact age of the South Pass Formation is unknown; however, it is certainly younger than the Arikaree Formation (early and middle Miocene). Near the McCann Ranch, in secs. 4 and 5, T. 27 N., R. 103 W., and secs. 29, 30, 31, 32, and 33, T. 28 N., R. 103 W., the formation is displaced along the Continental fault, and the beds are tilted as much as $45^{\circ}$. The basal conglomerate along the Continental fault is noticeably cemented, whereas elsewhere the conglomerate is generally semiconsolidated. If the latest movement along the Continental fault is post-middle Pliocene, which regional evidence indicates (Love, 1954, p. 1312), the South Pass Formation may be considered to be late Miocene to middle Pliocene in age. Traced eastward, discontinuous outcrops indicate that the South Pass grades into fossiliferous rocks assigned to the Ogallala Formation (upper Miocene and Pliocene) in southeastern Wyoming, and because the formation has lithologic, 
stratigraphic, and structural relations similar to those of the Ogallala, a correlation between the two formations is suggested.

\section{QUATERNARY ROCKS}

\section{OIDEST STREAM GRAVEL DEPOSIT}

The oldest stream gravel found in the Oregon Buttes area is in the northwest and southwest corners of the map area (pl. 1 ; sec. 4, T. 27 N., R. 104 W., and sec. 29, T. 28 N., R. 104 W., along Little Sandy Creek; sec. 31, T. 28 N., R. 103 W., 2 miles west of McCann Ranch; and secs. 4 and 5, T. 25 N., R. 104 W., 21/2 miles north of Tule Butte). This gravel (fig. 8) along Little Sandy Creek is about 160 feet above the present valley at an altitude of about 7,000-7,300 feet. North of Tule Butte the gravel is at an altitude of about 6,960 feet, and it is 160 feet above Jack Morrow and Pacific Creeks. This oldest and highest gravel is characterized by well-rounded stratified cobbles of quartzite not found in younger terraces. Red quartzite, chert, jasper, and yellowish-brown petrified wood are characteristic components of only this gravel, and the writers used these rock types to trace the remnants of this drainageway. Carbonaceous and partially silicified brown and black petrified wood is also found in this gravel in the northern end of the area near Little Sandy Creek (pl. 1).

The gravel making up the Camp terrace of Moss (1951, p. 73), exposed 5 miles southwest of the map area, is equivalent to the oldest and highest stream gravel deposit just discussed. Moss described the cobbles in the deposit to be led, green, and white quartzite in contrast to a large proportion of granitic cobbles on the lower terraces. Outcrops of the Camp terrace are southwest of the map area along State Highway 28 northeast of Farson (fig. 8) at an altitude of about 6,850 feet and about 150 feet above Pacific Creek.

Moss $(1951$, p. 73 ) also discussed the possible source of the quartzite cobbles in the higher Camp terrace and suggested several possibilities: (1) small lenses of red and green quartzite in the Wasatch Formation along Big Sandy Creek, (2) red and green quartzite on higher terraces at Boulder Creek, northwest of the Big Sandy drainage, or (3) the quartzite-rich Pinyon Conglomerate cropping out in the northern part of the Green River Basin. The writers favor the Paleocene Pinyon Conglomerate and older terraces as the probable source for the quartzite.

A remnant of this highest gravel, containing red and white quartzite and yellowish-brown petrified wood, caps Fifteenmile Knoll (fig. 8) $3 \frac{1}{2}$ miles south of the Boars Tusk in the upper part of Killpecker Creek valley. This gravel remnant lies 80 feet above the present valley at an altitude of 6,680 feet and is 15 miles south of Tule Butte. 


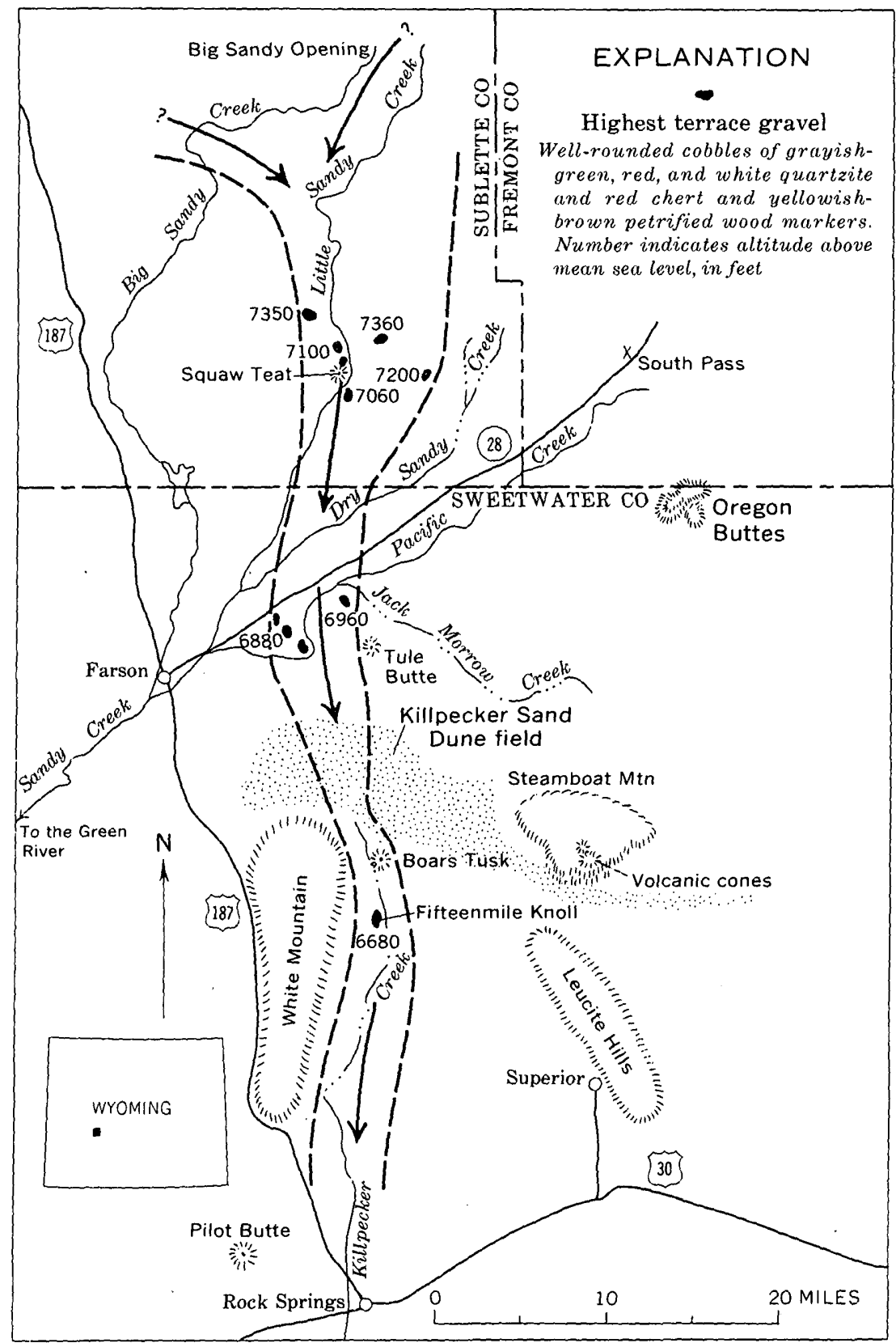

Figure 8.-Possible drainageway during early Pleistocene time (arrows). 
Interbedded near the top of this gravel is a volcanic ash which resembles in some respects the Pearlette Ash Member of the Sappa Formation of late Kansan age of the Great Plains, but more study of Quaternary ash beds is necessary to establish correlation (R. E. Wilcox, written commun., 1967).

The scattered outcrops of this highest gravel suggest that in early Pleistocene time a stream flowed either from the west or from the part of the Wind River Range north of Big Sandy opening, ran south from the vicinity of Squaw Teat (pl. 1; fig. 8), passed the west side of Tule Butte, crossed the area now covered by the Killpecker Sand Dune field, and flowed down Killpecker Creek valley east of White Mountain. Volcanism, especially flows and ash falls, in the Leucite Hills could have been responsible for diverting the old drainage westward into its present course to the Green River.

\section{OTHER QUATERNARY DEPOSTTS}

Other Quaternary deposits in the map area include younger terrace gravels, pediment gravels, colluvium, landslide deposits, sand, and alluvium.

The lower terrace gravels contain cobbles and boulders of granite and darker igneous and metamorphic rocks. They occur along Little Sandy Creek in the northwestern part of the area.

Pediment gravels including sand and silt occur near Oregon Buttes and extend into the Great Divide Basin ; stringers of gravel dip northward from the Continental fault scarp and are preserved along minor divides in the area.

The colluvium, which is made up of unstratified slope wash and talus, occurs along the north side of the Continental fault scarp. A mile east of the Sinclair Oil Co. Oregon Trail Unit 1 Govt. well, patches of colluvium contain boulders, which are more than 10 feet in diameter, derived from conglomerates in the Wasatch Formation.

Landslide deposits are present on the northwest slope of Oregon Buttes and almost surround the summit of Continental Peak. These deposits include blocks of sandstone, siltstone, and claystone of the Arikaree and Bridger Formations and the Laney Shale Member of the Green River Formation that have moved down steep slopes. Landslides of rocks of the Laney are present also on the east side of Joe Hay Rim.

Two major deposits of wind-deposited sand occur in the area. One deposit, 6 miles southeast of Continental Peak, includes about 5 square miles of windblown sand and silt and some stationary sage- and grasscovered dunes. The other deposit, 5 miles southwest of Oregon Buttes, covers about 2 square miles. Gravel, sand, silt, and clay fill valleys in 
the area, but is probably less than 50 feet thick in most valleys. The most extensive amount of alluvium fills the valley of Pacific Creek and its tributaries and the valley of the Sweetwater River.

\section{STRUCTURAL FEATURES}

The index map (fig. 1) shows the relation of the Oregon Buttes area to the major regional structural features. The central part of the area mapped lies on a structural platform which joins the Rock Springs uplift to the Wind River Range. The uplift separates the Green River and Great Divide Basins. The western third of the map area is within the Green River Basin, and the southeastern part is within the Great Divide Basin. Normal faults occur along the northwest flank of the Rock Springs anticline in T. 25 N., R. 103 W., and the Continental fault zone along the north margin. The most spectacular local structural feature is Reds Cabin monocline, which is well exposed near the center of T. $27 \mathrm{~N}$., R. $101 \mathrm{~W}$. The monocline probably formed as a result of movement on the Wind River thrust fault (pl. 1). The trace of the buried thrust fault is shown east of the monocline in secs. 25 and 26, T. 27 N., R. 101 W., and secs. 29 and 30, T. 27 N., R. $100 \mathrm{~W}$. The trace is not shown in other places because of lack of information.

\section{FAULTS}

Most of the faults in the map area are associated with the Continental fault system, which trends slightly north of west across the northern part of the area. The name Continental fault was applied by Nace $(1939$, p. 45$)$ to a major fault system which extends along the southwest flank of the Wind River Range for 50 and perhaps as many as 80 miles. The rocks along the main fault and subparallel associated faults are downdropped on the north. The Bridger and Arikaree Formations are exposed on the downthrown block in T. 27 N., Rs. 99-101 W., and the eastern half of T. 27 N., R. 102 W. The Bridger Formation is exposed westward from the middle of T. 27 N., R. 102 W., to the west margin of the map area. Except directly north of Continental Peak where the Laney Shale Member is faulted against the Bridger Formation, the Wasatch Formation is exposed on the upthrown block of the fault in the map area.

The total displacement is difficult to determine. Nace $(1939$, p. 46) estimated it to be 1,450 feet by comparing the altitude of the top of the Bridger Formation on Oregon Buttes with the top of that formation on the north side of the fault and adding 450 feet for Reds Cabin monocline. The difference in altitude between the top of the Bridger on the north butte of Oregon Buttes and at a place near Dickie Springs in sec. 15, T. 27 N., R. 101 W., north of the Con- 
tinental fault, is 750 feet. Southerly dips of $1^{\circ}$ were estimated on the north butte of Oregon Buttes and in sec. 24, T. 27 N., R. $101 \mathrm{~W}$; southerly dips of $5^{\circ}$ were measured at two localities along the crest of Pacific Butte in secs. 11 and 12, T. 27 N., R. 102 W. Thus, a dip of half a degree basinward on the erosion surface beneath the Arikaree would increase the calculated displacement 650 feet and would result in a total displacement of about 1,400 feet (structure section, pl. 1). The amount of displacement appears to decrease eastward and restward from Dickie Springs. The north block is displaced downward about 900 feet north of Continental Peak and about the same distance near Little Sandy Creek.

The fault plane is well exposed at only two localities: near the center of sec. 2, T. 27 N., R. 103 W., where it dips $80^{\circ}$ NW., and in the NE cor. sec. 17, T. 27 N., R. 101 W., where it dips $65^{\circ}$ NE. The trace of the main fault plane is sinuous, whereas the traces of the subparallel faults are nearly straight.

Near the McCann Ranch, the Continental fault tilts beds of the South Pass Formation as much as $45^{\circ}$ (p. 23). Regional evidence (Love, 1954, p. 1312) indicates that latest movement along the Continental fault is post-middle Pliocene.

The rocks along a northeast-trending normal fault in the $\mathrm{S} 1 / 2$ sec. 30 and the N1/2 sec. 31, T. 27 N., R. 101 W., are displaced about 55 feet downward on the northwest side. A bed of gravel which caps a butte there is not affected by the fault although the underlying bedrock is displaced.

A series of subparallel northeast-trending normal faults are in T. 25 N., R. 103 W. One of these extends across sec. 36, T. 26 N., R 103 W., into the southwestern part of T. 26 N., R. 102 W., and another extends into the northwestern part of T. 25 N., R. $102 \mathrm{~W}$. The faults roughly parallel the axis of the Rock Springs anticline and are all on its northwest limb. On all the faults, except the one closest to the axis of the anticline, the rocks are downdropped on the southeast and thus steepen the west limb of the anticline, and along this limb, weathering has formed a series of hogback ridges. Displacement of the rocks along the main faults ranges between 250 and 150 feet. The downdropped block between the fault closest to the anticline axis and the one adjacent on the west is called the Packsaddle graben.

A concealed thrust fault is shown on the map (pl. 1) in the southeastern part of T. 27 N., R. 101 W., and the southwestern part of T. 27 N., R. 100 W. The fault is called the Wind River thrust fault, after a major thrust fault mapped by G. M. Richmond in the northern part of the Wind River Range (Richmond, 1945); it has been extended in the subsurface along the entire southwest flank of the 
Wind River Range by R. R. Berg (1962, p. 2020). In the map area, the position of the fault is indicated by the logs of two holes drilled for oil and gas, the British American Oil Co. McClintock 1 Govt. well in the SW $1 / 4$ sec. 30, T. 27 N., R. 100 W., and the Sinclair Oil Co. Oregon Trail Unit 1 Govt. well in the NE1/4NW1/4 sec. 24, T. 27 N., R. 101 W. The British American well was drilled to a depth of 11,012 feet and bottomed in the Fort Union Formation of Paleocene age or the Lance Formation of Late Cretaceous age. The Sinclair well was drilled to a depth of 1,857 feet and penetrated the top of the Precambrian rocks at about 1,100 feet. The trace of the thrust fault shown on plate 1 is alined with the axis of a sharp monoclinal fold in secs. 17, 20, and 21, T. 27 N., R. 101 W., which may have been formed by movement of the thrust block after deposition of the Eocene sediments.

\section{FOLDS}

Folds are scarce in the map area, and dips are generally less than 60 feet per mile. Most of the folds are associated with the Continental fault and the Wind River thrust fault in the northern part of the area. The axial trace of the Rock Springs anticline passes northeastward through the western part of T. 25 N., R. 102 W., and to sec. 27, T. 26 N., R. 102 W. A northeast-trending syncline in secs. 14 and 23 , T. 26 N., R. 102 W., is probably associated with the folding of the Rock Springs anticline. Petroleum geologists interpret the Rock Springs anticline to plinge northeastward, and this interpretation has been the basis for drilling several wells for oil and gas, including the Atlantic Refining Co. Plunge Unit 2 Govt. well in the $S W 1 / 4$ NW1/4 sec. 17, T. 25 N., R. 102 W., the Pan American Petroleum Corp. Belfer 1 Govt. well in the SW1/4NW1/4 sec. 3, T. 25 N., R. 102 W., and the Pan American Corp. Belfer B1 Govt. well in the SW1/4 NW1/4 sec. 9, T. 25 N., R. 102 W. All three wells are on or near the axis of the Rock Springs anticline. Kerr-McGee Oil Industries tried a different approach and drilled Morrow Creek Unit 1 Govt. well in the $\mathrm{SE} 1 / 4$ sec. 9, T. 25 N., R. $103 \mathrm{~W}$., downdip from the westernmost fault on the northwest limb of the anticline. All four test holes are dry and abandoned.

The Reds Cabin monocline trends northwest in secs. 20 and 21 , T. 27 N., R. 101 W., and the steep southward-dipping limb is well exposed for nearly 2 miles. Several canyons breach the structure and reveal massive beds of arkosic sandstone of the Wasatch Formation. The most scenic canyon is at the southern end of the monocline near the SE cor. sec. 21. The canyon is shaped like an amphitheater and has a narrow gateway in steeply dipping sandstone. The same sandstone forms the rim of the bowl nearly 300 feet above. By strict def- 
inition, the monocline is actually an asymmetric anticline because the beds northeast of the anticlinal axis dip toward the Hay syncline on the north. The abrupt change from dips of $1^{\circ}$ to dips steeper than $50^{\circ}$, however, makes the term "monocline" more descriptive. The axis of the Hay syncline is parallel to the axis of the monocline and passes northwestward through secs. $22,21,16$, and 17 nearly to the trace of the Continental fault.

That these folds are not parallel to the trace of the Continental fault and that no similar structures lie along the fault suggest that folds are not related to the Continental fault. The folds may be alined with the trace of the buried Wind River thrust fault and, therefore, may have formed as a result of movement of the thrust plate after deposition of the lower and middle Eocene sediments. Some evidence indicates that the second movement of the thrust plate followed the period of normal faulting which produced the Continental fault. The trace of the fault plane is quite sinuous. Some beds on both the downthrown and upthrown blocks dip toward the south and southwest rather than toward the north and northeast. There is a series of small folds in rocks on the downthrown block whose axes closely follow the bends in the trace of the Continental fault. These features can be explained by a southwestward movement of the downthrown northern block producing contortions in the fault plane paralleled by folding in the rocks of the northern block and tilting of the beds on both sides of the fault toward the south and southwest. The buried wedge of Precambrian rocks, too rigid to be deformed, was tilted toward the vertical and the southern end was thus raised to form the Reds Cabin monocline and the Hay syncline. Since the monocline does not cover the entire width of the toe of the thrust, a buried transverse fault may have limited the length of the raised Precambrian segment.

\section{GEOLOGIC HISTORY}

No sedimentary rocks older than the early Eocene are exposed in the map area. For accounts of pre-Eocene history of the general region, reference is made to Wyoming Geological Association (1955).

In the local physiographic setting in which Eocene sediments were deposited, the Wind River Range had been elevated, sedimentary rocks stripped off, and the granite core exposed. Arkose and mudstone sediments of the Wasatch Formation were deposited by streams on flood plains in a broad basinlike area which included the present Green River, Great Divide, and Washakie Basins and the Rock Springs anticline. Locally, coal deposits accumulated in discontinuous swampy areas in the valley. 
Late in early Eocene time, rainfall increased or stream runoff from the basin areas was impounded, and lacustrine deposits of the Green River Formation were laid down in the resultant lake. During late early Eocene and early middle Eocene, the margins of the lake fluctuated widely. Evaporite minerals were deposited in the lake during periods of greatest restriction, and fluviatile and lacustrine deposits alternated in the intermarginal areas. The south end of the Wind River Range was re-elevated during deposition of the last sheet of Wasatch fluviatile sediments. Boulder beds are common in the upper part of the Wasatch Formation along the Continental fault scarp in T. 27 N., Rs. 101 and 102 W., and on the southwest flank of the Prospect Mountains in T. 29 N., Rs. 103 and 104 W.; many boulders are 10 feet in diameter, and several have a diameter greater than 15 feet.

The lake expanded again, reaching farther northeast in the Oregon Buttes area than it had formerly; then it began to recede, and fluviatile deposition of the Bridger Formation dominated the steadily sinking basin. Detrital material in the Bridger Formation is much finer grained than in the Wasatch and contains a high percentage of volcanic ash. Small discontinuous lakes developed periodically in the basin areas during deposition of the Bridger Formation.

No depositional record of upper Eocene or Oligocene sediments remains in the Oregon Buttes area, but regional evidence indicates that these sediments were deposited and subsequently eroded before deposition of the basal Miocene conglomerate. The abrupt and great change in grain size of the detrital material deposited in Oligocene time to that of the clastic materials making up the basal Arikarese conglomerate (early and middle Miocene) indicates that the W.ind River Range was gently elevated prior to Miocene time. The composition of boulders and cobbles in the basal Arikaree conglomerate indicates that stripping of the Wind River Range had reached the point where Precambrian metasediments flanking the granite core were being eroded and transported into the basin during early Miocene.

The average grain size of the detritus deposited in the Miocene gradually became smaller, and a thick sequence of water- and windlaid very tuffaceous sandstone and siltstone was deposited in the valley through middle Miocene time. The Wind River Range was again raised, and lower Miocene sediments were trenched and in places completely removed. Sediments of conglomeratic sequence (South Pass Formation) of highly variable lithology were deposited by running water and in small local lakes through late Miocene and early Pliocene time. The south end of the Wind River Range was downdropped along the Continental fault in middle Pliocene time as part of a regional mountain-front faulting (Love, 1954, p. 1311). 
The south scarp of the Continental fault was breached by numerous mountain streams and possibly by a river flowing down the valley from the north. These streams and rivers left local terrace deposits as they cut through the soft Tertiary rocks. One high-level terrace appears to be displaced across the fault and thus indicates a later downdrop of the Wind River Range along the Continental fault. A final movement of the Wind River Range contorted the trace of the Continental fault and folded the adjacent rocks.

\section{ECONOIIIC GEOLOGY}

No minerals have been produced from the Oregon Buttes area as of 1967 , but the area has a potential for oil and gas, gold, and uranium production. Much high-quality coal underlies the southern part of the area, but it is too far below the surface to be economical at present. Some low-grade oil shale is in the northeast and southwest corners of the map area.

\section{COAL}

Although no coal beds crop out within the map area, the part of the area south of the Wind River thrust fault is underlain by a coalbearing sequence approximately 1,200 feet thick that has an aggregate thickness of as much as 100 feet of coal and contains several coal beds more than 15 feet thick. This coal sequence is buried beneath $2,300-5,000$ feet of younger rocks. The coal-bearing sequence is tentatively correlated with the Black Rock coal group of Paleocene age of the northern part of the Rock Springs anticline (Schultz, 1920). Schultz considered the Black Rock coal group to constitute the lower part of the Wasatch Formation of early Eocene age. Later, plants of Paleocene age were found in the sequence, and now it is considered to correlate with the Fort Union Formation of Paleocene age (Pipiringos, 1961.p. 26)

Six wells drilled for oil and gas in the map area penetrated the coal-bearing sequence. Six additional wells within 3 miles of the south boundary of the area penetrated the sequence. Individual coal beds seem to be discontinuous except for a zone near the top of the sequence and another zone near the middle (fig. 9). The number of coal beds and the total thickness of coal decrease northward. The log of the Atlantic Refining Co. Plunge Unit 2 Govt. well in the NW1/4 sec. 17, T. 25 N., R. 102 W., shows nine coal beds with an aggregate thickness of 100 feet. A coal bed 5 feet thick was penetrated by the Superior Oil Co. Pacific Creek Unit 1 Govt. well in the SW1/4 sec. 27 , T. 27 N., R. 103 W., and about seven thin streaks of coal were 
penetrated by the British American Oil Co. McClintock 1 Govt. well in the SW1/4 sec. 30, T. 27 N., R. 100 W. The U.S. Bureau of Mines analyzed drill cuttings and cores of coal from the coal-bearing sequence and reported that the coal has an average heating value of about $12,000 \mathrm{Btu}$ per ton on an as-received basis (table 2).

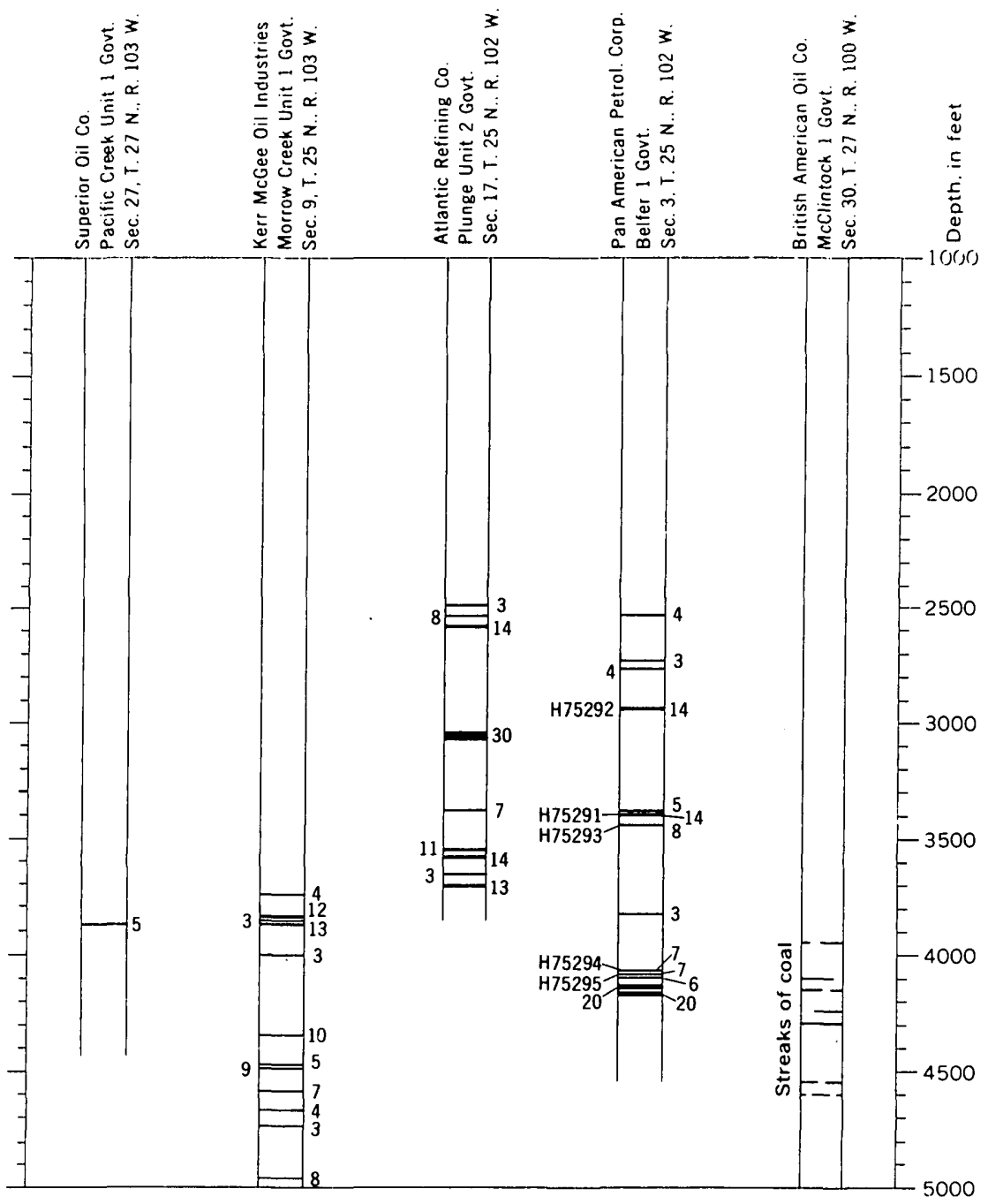

FIgURE 9.-Distribution and depth of coal beds in the coaly interval of the Fort Union Formation. Thickness of coal beds shown in feet. U.S. Bureau of Mines sample numbers shown in table 2 are given opposite the beds sampled in the Pan American well. 
TABLE 2.-Analyses of samples of coal obtained from oil test holes in the Oregon Buttes area and areas to the south

[Analyses by U.S. Bureau of Mines]

\begin{tabular}{|c|c|c|c|c|c|c|c|}
\hline \multirow{2}{*}{$\underset{(\mathrm{ft})}{\text { Interval }}$} & \multirow[t]{2}{*}{ Sample } & \multirow[t]{2}{*}{ Condition } & \multirow{2}{*}{$\begin{array}{l}\text { Heating } \\
\text { value } \\
\text { (Btu) }\end{array}$} & \multicolumn{3}{|c|}{ Proximate analyses, in percent } & $\begin{array}{l}\text { Ultimate } \\
\text { analysis, } \\
\text { in percent }\end{array}$ \\
\hline & & & & $\begin{array}{c}\text { Mois- Volatile } \\
\text { ture matter }\end{array}$ & $\begin{array}{l}\text { Fixed } \\
\text { carbon }\end{array}$ & Ash & Sulfur \\
\hline
\end{tabular}

Pan American Petroleum Corp., Belfer 1 Govt., sec. 3, T. 25 N., R. 102 W.

[Samples from well cuttings]

\begin{tabular}{|c|c|c|c|c|c|c|c|c|}
\hline $2,937-2,951$ & $\mathrm{H}-75292$ & $\begin{array}{l}\text { As received } \\
\text { Moisture free } \\
\text { Moisture and ash free. }\end{array}$ & $\begin{array}{l}11,370 \\
12,090 \\
13,220\end{array}$ & $\begin{array}{c}5.9 \\
-1-2\end{array}$ & $\begin{array}{l}34.1 \\
36.2 \\
39.6\end{array}$ & $\begin{array}{l}52.0 \\
55.3 \\
60.4\end{array}$ & $\begin{array}{l}8.0 \\
8.5\end{array}$ & $\begin{array}{r}0.5 \\
.5 \\
.6\end{array}$ \\
\hline $3,396-3,410$ & H-75291 & $\begin{array}{l}\text { As received } \\
\text { Moisture free } \\
\text { Moisture and ash free }\end{array}$ & $\begin{array}{l}11,960 \\
12,590 \\
13,580\end{array}$ & 5.0 & $\begin{array}{l}37.5 \\
39.4 \\
42.5\end{array}$ & $\begin{array}{l}50.6 \\
53.3 \\
57.5\end{array}$ & $\begin{array}{l}6.9 \\
7.3\end{array}$ & $\begin{array}{l}.4 \\
.4 \\
.4\end{array}$ \\
\hline $3,440-3,448$ & $\mathrm{H}-75293$ & $\begin{array}{l}\text { As received } \\
\text { Moisture free } \\
\text { Moisture and ash free.... }\end{array}$ & $\begin{array}{l}11,070 \\
12,050 \\
13,450\end{array}$ & 8.1 & $\begin{array}{l}32.6 \\
35.5 \\
39.6\end{array}$ & $\begin{array}{l}49.7 \\
54.1 \\
60.4\end{array}$ & $\begin{array}{r}9.6 \\
10.4\end{array}$ & $\begin{array}{l}.5 \\
.6 \\
.7\end{array}$ \\
\hline $4,076-4,083$ & $\mathrm{H}-75294$ & $\begin{array}{l}\text { As received } \\
\text { Moisture free } \\
\text { Moisture and ash free. }\end{array}$ & $\begin{array}{l}12,480 \\
12,970 \\
13,760\end{array}$ & 3.8 & $\begin{array}{l}35.7 \\
37.1 \\
39.4\end{array}$ & $\begin{array}{l}55.0 \\
57.2 \\
60.6\end{array}$ & $\begin{array}{l}5.5 \\
5.7\end{array}$ & $\begin{array}{r}.4 \\
.4 \\
.4\end{array}$ \\
\hline $4,085-4,092$ & $\mathrm{H}-75295$ & $\begin{array}{l}\text { As received } \\
\text { Moisture free } \\
\text { Moisture and ash free... }\end{array}$ & $\begin{array}{l}12,740 \\
13,240 \\
13,820\end{array}$ & \begin{tabular}{c}
3.8 \\
\hdashline$-1-1$
\end{tabular} & $\begin{array}{l}39.7 \\
41.3 \\
43.1\end{array}$ & $\begin{array}{l}52.5 \\
54.5 \\
56.9\end{array}$ & $\begin{array}{r}4.0 \\
4.2 \\
-\end{array}$ & $\begin{array}{l}.4 \\
.4 \\
.5\end{array}$ \\
\hline
\end{tabular}

Rowan-Bass Govt. 1, sec. 2, T. 24 N., R. 100 W.

[Samples from well cuttings]

\begin{tabular}{|c|c|c|c|c|c|c|c|c|}
\hline $2,878-2,883$ & $\mathrm{H}-46786$ & $\begin{array}{l}\text { As received } \\
\text { Moisture free } \\
\text { Moisture and ash free.... }\end{array}$ & $\begin{array}{l}10,470 \\
11,560 \\
13,680\end{array}$ & \begin{tabular}{c}
9.4 \\
\hdashline$-1-$
\end{tabular} & $\begin{array}{l}35.2 \\
38.9 \\
46.0\end{array}$ & $\begin{array}{l}41.4 \\
45.6 \\
54.0\end{array}$ & $\begin{array}{l}14.0 \\
15.5\end{array}$ & $\begin{array}{l}2.4 \\
2.7 \\
3.1\end{array}$ \\
\hline $3,066-3,082$ & $H-46788$ & $\begin{array}{l}\text { As received } \\
\text { Moisture free } \\
\text { Moisture and ash free. }\end{array}$ & $\begin{array}{l}10,580 \\
12,020 \\
13,520\end{array}$ & 12.0 & $\begin{array}{l}32.8 \\
37.3 \\
42.0\end{array}$ & $\begin{array}{l}45.4 \\
51.6 \\
58.0\end{array}$ & $\begin{array}{c}9.8 \\
11.1\end{array}$ & $\begin{array}{l}2.3 \\
2.7 \\
3.0\end{array}$ \\
\hline $3,106-3,114$ & $\mathrm{H}-46787$ & $\begin{array}{l}\text { As received } \\
\text { Moisture free } \\
\text { Moisture and ash free. }\end{array}$ & $\begin{array}{l}11,290 \\
12,540 \\
13,500\end{array}$ & \begin{tabular}{l}
9.9 \\
\hdashline-1
\end{tabular} & $\begin{array}{l}33.0 \\
36.6 \\
39.4\end{array}$ & $\begin{array}{l}50.7 \\
56.3 \\
60.6\end{array}$ & $\begin{array}{c}6.4 \\
7.1 \\
-.-\end{array}$ & $\begin{array}{l}.7 \\
.8 \\
.8\end{array}$ \\
\hline $4,390-4,416$ & $\mathrm{H}-46789$ & $\begin{array}{l}\text { As received } \\
\text { Moisture free } \\
\text { Moisture and ash free.... }\end{array}$ & $\begin{array}{l}12,210 \\
13,230 \\
14,050\end{array}$ & 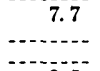 & $\begin{array}{l}37.7 \\
40.9 \\
43.4\end{array}$ & $\begin{array}{l}49.2 \\
53.3 \\
56.6\end{array}$ & $\begin{array}{l}5.4 \\
5.8 \\
-\end{array}$ & $\begin{array}{l}.4 \\
.4 \\
.5\end{array}$ \\
\hline $4,834-4,842$ & $\mathrm{H}-46791$ & $\begin{array}{l}\text { As received } \\
\text { Moisture free. } \\
\text { Moisture and ash free. }\end{array}$ & $\begin{array}{l}12,630 \\
12,960 \\
13,940\end{array}$ & 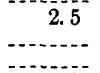 & $\begin{array}{l}33.8 \\
34.7 \\
37.3\end{array}$ & $\begin{array}{l}56.8 \\
58.2 \\
62.7\end{array}$ & $\begin{array}{l}6.9 \\
7.1\end{array}$ & $\begin{array}{r}.4 \\
.4 \\
.4\end{array}$ \\
\hline $7,158-7,166$ & $\mathrm{H}-46790$ & $\begin{array}{l}\text { As received } \\
\text { Moisture free } \\
\text { Moisture and ash free..... }\end{array}$ & $\begin{array}{l}13,190 \\
13,650 \\
14,610\end{array}$ & 3.3 & $\begin{array}{l}37.4 \\
38.6 \\
41.4\end{array}$ & $\begin{array}{l}52.9 \\
54.8 \\
58.6\end{array}$ & $\begin{array}{l}6.4 \\
6.6\end{array}$ & $\begin{array}{l}.6 \\
.6 \\
.6\end{array}$ \\
\hline
\end{tabular}

San Jacinto Oil and Gas Co. 1, sec. 27, T. 24 N , R. 102 W.

[Samples from core drilling]

\begin{tabular}{|c|c|c|c|c|c|c|c|c|}
\hline $3,570-3,575$ & H-57378 & $\begin{array}{l}\text { As received } \\
\text { Moisture free. } \\
\text { Moisture and ash free..... }\end{array}$ & $\begin{array}{l}12,070 \\
13,130 \\
13,790\end{array}$ & 8.1 & $\begin{array}{l}38.0 \\
41.4 \\
43.4\end{array}$ & $\begin{array}{l}49.5 \\
53.8 \\
56.6\end{array}$ & $\begin{array}{l}4.4 \\
4.8 \\
--2\end{array}$ & $\begin{array}{l}1.3 \\
1.5 \\
1.5\end{array}$ \\
\hline
\end{tabular}


Several wells penetrated thin lenticular coal beds in the overlying Wasatch Formation at depths of about 2,000 feet; these beds are probably an extension of the Wasatch coal beds in the Great Divide Basin described by Pipiringos (1961).

Many thick beds of coal in the Mesaverde Group of Cretaceous age have been penetrated by oil and gas test wells in and south of the map area; they extend farther north than the Paleocene coal beds, but they lie at depths greater than 5,000 feet in the map area.

\section{OIL AND GAS}

Oil and gas have been produced in the Green River and Great Divide Basins from many formations including the Wasatch, Fort Union, Mesaverde, Baxter, Frontier, Mowry, Dakota, and Nugget Formations (table 3). Gas has been produced from the Wasatch, Fort Union, Lewis, Mesaverde, Frontier, Dakota, Beckwith, Morrison, Nugget, and Tensleep Formations (Burk, 1955). The Pinedale anticline, located about 15 miles northwest of the map area, has yielded gas from rocks reported to be of early Tertiary age (Jenkins, 1955b). The G. L. Reasor Pacific Creek 1 Govt. well in sec. 28, T. 27 N., R. 103 W., produced gas from rocks reported to be in the Fort Union and Lance sequence (Jenkins, 1955a) and produced considerable gas from Upper Cretaceous rocks before it was plugged back because of excessive water. The well is classified as a shut-in gas well, but its remote location precludes connection with existing pipelines. Several dry holes in the area had promising shows of gas in the Fort Union, Lance, and Mesaverde Formations; but in all, pressure tended to drop off rapidly dur. ing drill-stem tests. Specialized completion and stimulation techniques need to be applied to realize the indicated potential of Fort Union, Lance, and Mesaverde reservoir rocks.

None of the wells drilled in the map area tested rocks older than the Late Cretaceous. To test for oil and gas in older reservoirs requires drilling to depths greater than 10,000 feet. Some deep drilling has shown very favorable results in Wyoming, and a few wells deeper than 10,000 feet have been completed in the southwestern part of the Washakie Basin ; a 1965 discovery in the Powder River Basin produces from the Mississippian at 16,000 feet. The untested deep reservoirs along the axis of the Rock Springs anticline also offer a promising target for deep drilling. Another area of possible entrapment of oil and gas is beneath the wedge edge of the Wind River thrust plate where potential Mesozoic and Paleozoic reservoir rocks are contorted and overturned (Berg, 1962). 


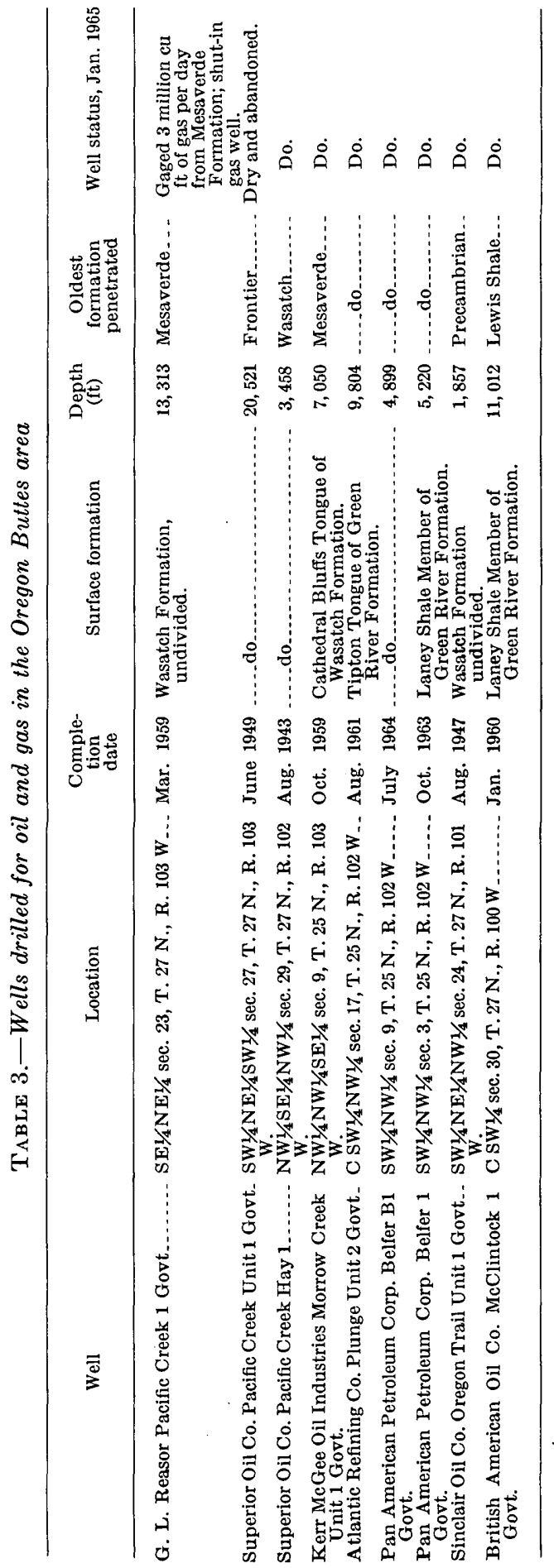




\section{OIL SHALE}

Some low-grade oil shale occurs in the Wilkins Peak and Laney Shale Members of the Green River Formation in the map area. One 3 -foot surface sample of marlstone from the Laney Shale Member (sec. 9, T. 26 N., R. 99 W.), analyzed by the U.S. Bureau of Mines, was estimated to contain 2.5 gallons of oil per ton of rock. A nearby core hole drilled by the U.S. Geological Survey in sec. 10, T. 26 N., R. $99 \mathrm{~W}$. (pl. 1 ; table 4), shows that this marlstone contains from 0 to 7.4 gallons per ton over a thickness of about 138 feet. The lower 35 feet of the rock drilled averaged about 3 gallons per ton (table 4).

TABLE 4.-Oil shale assays from U.S. Geological Survey Pinnacles $1 A$ core hole in the SW1/4 sec. 10, T. 26 N., R. 99 W., Sweetwater County

[Assays by U.S. Bureau of Mines Laramie Petroleum Research Center, Laramie, Wyo., on alr-dried samples by modified Fischer retort method]

\begin{tabular}{|c|c|c|c|c|c|c|c|c|}
\hline \multirow{3}{*}{ Sample } & \multirow{3}{*}{ Interval (ft) } & \multirow{3}{*}{ Run } & \multicolumn{6}{|c|}{ Yield of product } \\
\hline & & & \multicolumn{4}{|c|}{ Weight percent } & \multicolumn{2}{|c|}{ Gallons per ton } \\
\hline & & & O11 & Water & $\begin{array}{c}\text { Spent } \\
\text { shale }\end{array}$ & $\begin{array}{l}\text { Gas plus } \\
\text { loss }\end{array}$ & Oll 1 & Water \\
\hline 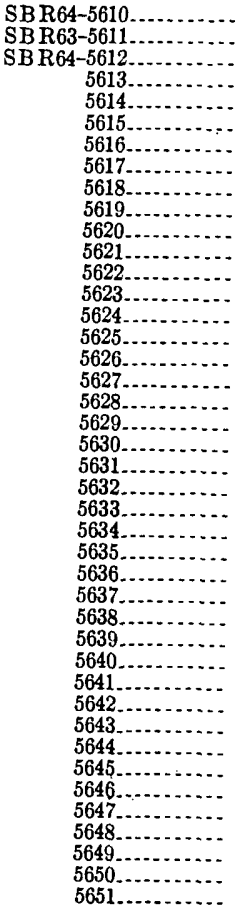 & $\begin{array}{r}20.4-21.5 \\
42.0-43.9 \\
49.0-49.3 \\
52.0-54.0 \\
54.0-56.0 \\
57.0-58.0 \\
59.0-60.4 \\
63.0-65.4 \\
65.4-67.0 \\
70.0-71.2 \\
71.2-73.0 \\
87.0-89.3 \\
89.3-90.8 \\
92.0-93.0 \\
93.0-94.6 \\
96.0-98.0 \\
98.0-99.7 \\
99.7-101.3 \\
101.3-103.0 \\
103.0-104.5 \\
104.5-105.5 \\
105.5-106.5 \\
106.5-107.5 \\
107.5-108.5 \\
108.5-110.0 \\
110.0-111.0 \\
111.0-112.0 \\
112.0-113.0 \\
113.0-114.0 \\
114.0-115.0 \\
115.0-117.0 \\
117.0-118.5 \\
118.5-120.0 \\
120.0-122.0 \\
122.0-124.0 \\
124.0-126.0 \\
126.0-128.0 \\
128.0-130.0 \\
130.0-132.0 \\
133.7-135.8 \\
135.8-137.0 \\
137.5-138.1 \\
5\end{array}$ & $\begin{array}{l}97494 \\
97495 \\
97496 \\
97497 \\
97498 \\
97499 \\
97500 \\
97501 \\
97502 \\
97503 \\
97504 \\
97505 \\
97506 \\
97507 \\
97508 \\
97509 \\
97510 \\
97511 \\
97512 \\
97513 \\
97514 \\
97515 \\
97516 \\
97517 \\
97518 \\
97519 \\
97520 \\
97521 \\
97522 \\
97523 \\
97524 \\
97525 \\
97526 \\
97527 \\
97528 \\
97529 \\
97530 \\
97531 \\
97532 \\
97533 \\
97534 \\
97535\end{array}$ & $\begin{array}{r}0.1 \\
.0 \\
1.5 \\
.2 \\
.2 \\
.0 \\
.1 \\
.1 \\
.1 \\
.2 \\
.1 \\
.1 \\
.1 \\
.1 \\
.2 \\
.1 \\
.8 \\
1.0 \\
.1 \\
1.1 \\
1.0 \\
.9 \\
1.4 \\
1.2 \\
1.6 \\
1.9 \\
1.8 \\
1.1 \\
1.3 \\
.9 \\
1.0 \\
1.5 \\
.7 \\
1.7 \\
1.4 \\
1.3 \\
1.8 \\
.8 \\
2.8 \\
.2 \\
.0\end{array}$ & $\begin{array}{r}5.0 \\
4.0 \\
5.7 \\
4.8 \\
3.8 \\
5.1 \\
3.5 \\
5.0 \\
2.4 \\
4.2 \\
2.9 \\
3.2 \\
3.1 \\
2.7 \\
2.9 \\
3.8 \\
4.4 \\
4.4 \\
4.8 \\
1.1 \\
4.3 \\
3.8 \\
4.3 \\
4.6 \\
5.2 \\
5.0 \\
5.6 \\
5.6 \\
5.4 \\
3.4 \\
6.5 \\
5.4 \\
6.2 \\
4.0 \\
5.0 \\
4.6 \\
5.4 \\
4.6 \\
4.8 \\
5.0 \\
2.6 \\
10.0\end{array}$ & $\begin{array}{l}93.3 \\
94.4 \\
92.0 \\
94.2 \\
95.7 \\
94.3 \\
93.3 \\
92.7 \\
96.8 \\
95.1 \\
95.8 \\
96.0 \\
96.4 \\
96.2 \\
96.6 \\
95.2 \\
95.1 \\
93.3 \\
92.9 \\
98.7 \\
92.8 \\
94.0 \\
93.2 \\
92.6 \\
92.1 \\
91.6 \\
91.3 \\
91.1 \\
92.2 \\
91.9 \\
91.6 \\
91.9 \\
91.3 \\
94.0 \\
91.9 \\
91.6 \\
91.9 \\
91.9 \\
92.8 \\
90.2 \\
95.8 \\
89.3\end{array}$ & $\begin{array}{r}1.6 \\
1.6 \\
.8 \\
.8 \\
.3 \\
.6 \\
3.1 \\
1.4 \\
.7 \\
.6 \\
1.1 \\
.7 \\
.4 \\
1.0 \\
.4 \\
.8 \\
.4 \\
1.5 \\
1.3 \\
.1 \\
1.8 \\
1.2 \\
1.6 \\
1.4 \\
1.5 \\
1.8 \\
1.2 \\
1.5 \\
1.3 \\
3.4 \\
1.0 \\
1.7 \\
1.0 \\
1.3 \\
1.4 \\
2.4 \\
1.4 \\
1.7 \\
1.6 \\
2.0 \\
1.4 \\
.7\end{array}$ & $\begin{array}{r}0.3 \\
\text { No oll } \\
3.8 \\
.4 \\
.4 \\
\text { No oll } \\
.3 \\
2.3 \\
.3 \\
.2 \\
.5 \\
.3 \\
.4 \\
.3 \\
.3 \\
.6 \\
.3 \\
2.2 \\
2.6 \\
.3 \\
2.9 \\
2.6 \\
2.4 \\
3.8 \\
3.2 \\
4.2 \\
4.9 \\
4.7 \\
2.9 \\
3.4 \\
2.4 \\
2.5 \\
3.8 \\
1.7 \\
4.3 \\
3.5 \\
3.4 \\
4.7 \\
2.0 \\
7.4 \\
.4 \\
\text { No oll }\end{array}$ & $\begin{array}{r}12.0 \\
9.5 \\
13.7 \\
11.5 \\
9.1 \\
12.1 \\
8.4 \\
12.0 \\
5.8 \\
9.9 \\
7.0 \\
7.7 \\
7.3 \\
6.5 \\
6.8 \\
9.1 \\
10.5 \\
10.5 \\
11.5 \\
2.5 \\
10.3 \\
9.1 \\
10.3 \\
11.0 \\
12.5 \\
12.0 \\
13.4 \\
13.4 \\
12.9 \\
8.1 \\
15.6 \\
12.9 \\
15.0 \\
9.6 \\
12.0 \\
11.0 \\
12.9 \\
11.0 \\
11.5 \\
12.0 \\
6.2 \\
23.9\end{array}$ \\
\hline
\end{tabular}

1 Yields estimated by a rapid test-tube method; specific gravity estimated as 0.92 . 
In the southwest corner of the area the Wilkins Peak Member may contain low-grade oil shale; however, no analyses were made. Southwestward into the Green River Basin, high-grade oil shale has been reported from the Wilkins Peak and Laney Shale Members. In the Oregon Buttes area, thinning out of the sediments along the northern shoreline of ancient Lake Gosiute indicates that conditions were less favorable for the formation of oil shale.

\section{GOLD}

Several placer gold claims are near Dickie Springs in secs. 13, 14, and 15, T. 27 N., R. 101 W., Fremont County. The placer deposits evidently have been known since the late 1800's and have been worked intermittently since then. The source of the gold seems to be goldbearing conglomerates of the lower part of the Arikaree Formation that are exposed on the north side of the Continental fault. All the placer gold claims are on the downthrown side of the fault in alluvial deposits composed of the eroded conglomerates.

\section{URANIUM}

Just north of the map area on the southeast edge of Prospect Mountains, uranium minerals occur in sandstone and conglomerate that are probably in the Wasatch Formation undivided. The mineral deposits are about 7 miles north of the McCann Ranch in sec. 35, T. 29 N., R. 103 W., Sublette County.

Coarse-grained and conglomeratic beds of the Wasatch extend into the map area where they may also contain uranium minerals.

\section{STRATIGRAPHIC SECTIONS}

The following 15 stratigraphic sections were measured in the Oregon Buttes area by H. D. Zeller and E. V. Stephens with a Jacob's staff and Abney level during the field seasons of 1961-63. Locations of all 15 are shown on plate 1 by the numbers, and correlations of the first nine are shown in figure 3. 
1. Partial section of Bridger and Green River Formations on the west side of Tule Butte near the NW cor. sec. 22, T. 25 N., R. $104 \mathrm{~W}$.

Bridger Formation (in part):

Feet

13. Algal limestone, silicified; contains many ostracodes; caps hill...

12. Sandstone, moderate-grayish-orange, medium- to coarse-grained, crossbedded, poorly sorted; many clay pebbles and biotite flakes; forms slope. Beds $5 \mathrm{ft}$ thick of yellowish-gray siltstone 20 and $40 \mathrm{ft}$ above base. Most of unit concealed

11. Algal limestone; many ostracodes; silicified locally . . . . . . . . . . .

10. Sandstone, medium-grayish-orange, very fine- to medium-grained; much biotite; forms slope.

9. Channel sandstone and granule, pebble, and cobble conglomerate, lighter colored than unit 7, highly variable; scattered spherical concretions. Granule and pebble conglomerate stringers contain green-stained quartz and (or) chert and many gastropod, pelecypod, reptile, and mammal remains. Top $5 \mathrm{ft}$ is fossiliferous clay pebble conglomerate. Very fossiliferous granule conglomerate $2 \mathrm{ft}$ thick between 5 and $10 \mathrm{ft}$ above base; fossil collection D-563 from this conglomerate.

35. 0

8. Sandstone, light-gray, fine-grained, calcareous

7. Sandstone, moderate-grayish-orange, fine-grained, biotitic, massive, crossbedded; forms hoodoo-weathering cliff; contains lenticular beds, scattered clay pebbles and turtle and other fossil remains, many channels and discontinuous beds; becomes very fine grained sandstone to siltstone containing many cannonball-like concretions at the top. Many concretions, 0.5-2 ft in diameter, $22 \mathrm{ft}$ above base....................

6. Claystone and clayey siltstone, light-greenish-gray; darkchocolate-brown nodules as much as $0.5 \mathrm{ft}$ in diameter. Lower 6-10 ft is dusky-yellow sandstone. Unit forms slope . . . . . ...

5. Siltstone and claystone, light-greenish-gray

4. Sandstone, light-yellow-gray, fine-grained . . . . . . . . . . .

3. Siltstone and claystone, light-greenish-gray and light-yellowgray, dolomitic, fissile, platy. Unit forms flats and caps many small buttes.

32. 0

3. 0

13. 0

8. 0

2. Sandstone, light-yellowish-gray to dusky-yellow, very fine- to medium-grained, crossbedded, massive- to thin-bedded; forms hard ledge containing many dark-chocolate-brown concretions as much as $2 \mathrm{ft}$ in diameter $12 \mathrm{ft}$ above base.

20. 0

1. Siltstone to claystone, light-greenish-gray, fissile; contains finegrained biotitic sandstone ledges containing oolites formed on sand grains; dark-chocolate-brown nodules as much as $1 \mathrm{ft}$

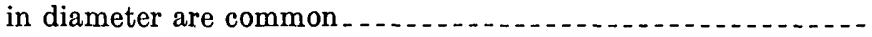

Measured thickness of Bridger Formation . 318.0 
1. Partial section of Bridger and Green River Formations on the west side of Tule Butte near the NW cor. sec. 22, T. $25 N ., R .104 W$.-Continued

Green River Formation (in part):

Laney Shale Member (in part):

3. Siltstone, light-yellowish-gray, dolomitic, platy; ostracodes and other remains; forms extensive flats . . . ..............

2. Limestone, light-grayish-orange (weatheis dark chocolate brown), sandy; ostracodes; ledge former. . . . . . . . . . . .

1. Sandstone, khaki, fine-grained, ashy, biotitic; weathers as a slope

Measured thickness of Green River Formation

2. Section of Wilkins Peak Member of the Green River Formation south of Jack Morrow Creek, NW1/4 sec. 19, T. 25 N., R. $103 \mathrm{~W}$.

Green River Formation:

Wilkins Peak Member:

Claystone and clayey and siliceous dolomite, moderate-grayishgreen (weathers light gray to white), fissile, platy. Analcitized ash bed about $0.5 \mathrm{in}$. thick, which weathers light grayish orange, $27 \mathrm{ft}$ above base. Siliceous dolomite, $0.5-0.75 \mathrm{in}$. thick, which weathers moderate grayish orange, $23 \mathrm{ft}$ above base

Total thickness of Wilkins Peak Member.

3. Section of Tipton Shale Member of the Green River Formation on a ridge east of South Packsaddle Canyon north of Jack Morrow Creek, NE 1/4 sec. 22, T. 25 N., R. $108 \mathrm{~W}$.

Green River Formation:

Tipton Shale Member:

17. Limestone, light-yellowish-gray, very fine grained, thinly Feet laminated; contains algal balls; described from float at top of hill. Unit forms top of Tipton Member.

1. 0

16. Mudstone, light-grayish-green. Algal heads with smooth laminae and brainlike surface $15 \mathrm{ft}$ above base. Algal limestone breccia $13-15 \mathrm{ft}$ above base; fragments about 3 $\mathrm{mm}$ to $0.1 \mathrm{ft}$ in diameter; contains much admixed sand. Algal balls as much as $2 \mathrm{ft}$ in diameter $11-13 \mathrm{ft}$ above base. Algal colonies $7 \mathrm{ft}$ above base; thin layered limestone crowns $0.2-0.5 \mathrm{ft}$ in diameter. Sand grains, pebbles, and many limestone pebbles and sandstone balls or fragments as much as $0.3 \mathrm{ft}$ in diameter $5-6 \mathrm{ft}$ above base.......-1

15. Sandstone, moderate-grayish-orange, medium-grained, calcareous, arkosic; bedding wavy to indistinct; weathers vuggy to rubbly. Slope mostly covered with scattered outcrops. Lowermost $7 \mathrm{ft}$ forms ledge 
3. Section of Tipton Shale Member of the Green River Formation on a ridge east of South Packsaddle Canyon north of Jack Morrow Creek, NE1/4 sec. 22, T. 25 N., R. 103 W.-Continued

Green River Formation-Continued

Tipton Shale Member-Continued

Feet

14. Sandstone, moderate-grayish-orange, medium- to finegrained, arkosic; bedding indistinct; concretions as much as $0.3 \mathrm{ft}$ in diameter, some contain quartz crystals. Outcrops scattered in mostly covered slope. Some thin beds $20 \mathrm{ft}$ above base. Ledge $4 \mathrm{ft}$ high at base................

13. Siltstone to very fine grained sandstone, light-grayishorange; slope mostly covered.

12. Sandstone, moderate-grayish-orange, arkosic, biotitic, friable, massive; contains tabular, spheroidal, and prolate concretions.

11. Sandstone, medium-yellowish-gray, fine-grained, soft, wavybedded; forms a concretion-covered slope. Ledge-forming bed $20 \mathrm{ft}$ above base.

10. Sandstone, moderate-grayish-orange, fine-grained; contains some biotite; mostly massive; bedding indistinct; ledge former. Iron-cemented concretions as much as $1 \mathrm{ft}$ in dia-

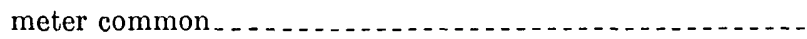

9. Sandstone, medium-yellowish-gray, fine-grained, very thin bedded; unit mostly covered.

8. Paper shale, grayish-olive-brown ......................

7. Sandstone, pale-grayish-orange, fine-grained, calcareous, biotitic; ledge former . . . . . . . . . . . . . . . . . . . .

6. Paper shale, pale-olive

5. Siltstone, light-olive-gray, fissile; slope mostly covered. Basal $2 \mathrm{ft}$ sandstone, pale-olive-brown, very fine grained, biotitic .

4. Paper shale, grayish-olive-brown to pale-olive

3. Limestone, grayish-orange, slabby, oolitic, pisolitic; contains

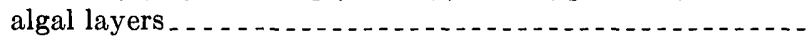

2. Limestone, light-grayish-orange, thin-bedded, oolitic; forms a slope.

1. Limestone, argillaceous, light-grayish-orange; contains many ostracodes, pelecypods, Goniobasis, and other gastropods, oolites at top; forms.ledge 
4. Section of Wilkins Peak Member of the Green River Formation, Cathedral Bluffs Tongue of the Wasatch Formation, and part of the Tipton Shale Member of the Green River Formation in the canyon of the tributary of Jack Morrow Creek just east of South Packsaddle Canyon, SW1/4 sec. 14, T. 25 N., R. $103 \mathrm{~W}$.

\section{Green River Formation:}

Wilkins Peak Member:

6. Dolomite or marlstone, pale-olive, papery to thin-bedded, carbonaceous; contains abundant plant fragments and fish and insect remains. Many dark-grayish-brown, light-grayish-orange-weathering concretions, $0.1-0.3 \mathrm{ft}$ in diameter, which may be small silicified algal colonies. Orange marker bed about $2 \mathrm{~mm}$ thick about $5 \mathrm{ft}$ above base. . ..........

Total thickness of Wilkins Peak Member. . . . . . .

Wasatch Formation:

Cathedral Bluffs Tongue:

5. Limestone; contains masses of algal tubes and coarse algae as much as $3 \mathrm{ft}$ in diameter; partly silicified.

4. Mudstone, dark- to pale-grayish-green; contains scattered quartz granules. Silicified nodules as much as $0.2 \mathrm{ft}$ in

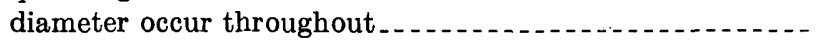

Total thickness of Cathedral Bluffs Tongue . . . . . . . .

Green River Formation:

Tipton Shale Member (in part):

3. Limestone, composed of small algal balls, light-yellowish-gray, very fine grained; thin laminae; contains rough algal-covered logs as much as $0.5 \mathrm{ft}$ in diameter, algal cases as much

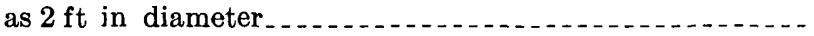

2. Mudstone and claystone, grayish-green, dolomitic...........

1. Limestone, composed of algal balls, light-yellowish-gray, very fine grained; thin laminae; algal heads as much as $1 \mathrm{ft}$ in diameter with crenulated surface similar to a brain.......

Measured thickness of Tipton Shale Member

5. Section of Laney Shale and Wilkins Peak Members of the Green River Formation along Parnell Creek near the center of sec. 24, T. $25 \mathrm{~N}$., R. 102 W.

Green River Formation:

Laney Shale Member (in part):

4. Siltstone and sandstone, medium-yellowish-gray, limy, ledgy,

flaggy; abundant plant remains ....................

3. Paper shale, moderate-grayish-brown

2. Claystone, grayish-green; contains argillaceous white limestone and limy white volcanic ash...... 8

Measured thickness of Laney Shale Member....... 130 
5. Section of Laney Shale and Wilkins Peak Member's of the Green River Formation along Parnell Creek near the center of sec. 24, T. 25 N., R. $102 \mathrm{~W}$.-Continued

Green River Formation-Continued

Wilkins Peak Member:

1. Claystone, moderate-greenish-brown (weathers very light brown), fissile; green clay parting in middle. Lower part contains abundant plant fragments.............. 10

Total thickness of Wilkins Peak Member. ........ 10

Wasatch Formation:

Cathedral Bluffs Tongue:

Mudstone, grayish-green; algal limestone beds. Not measured.

6. Section of part of the Arikaree Formation, the Bridger Formation, and the Laney Shale Member of the Green River Formation on Oregon Buttes from the center of sec. 14 to the $S W 1 / 4$ sec. 11, T. 26 N., R. $101 \mathrm{~W}$.

Arikaree Formation:

Feet

70. Sandstone and siltstone, tuffaceous; scattered granules. Snowwhite ash bed $1 \mathrm{ft}$ to $8 \mathrm{in}$. in diameter $150 \mathrm{ft}$ above base. Moss agate zone $130 \mathrm{ft}$ above base $\ldots \ldots$

69. Pebble conglomerate. Pebbles are fine-grained grayish-black, black, and greenish-black rocks of unidentified age and milky quartz, green phyllites, orthoclase, and black amphibolites derived from rocks of Precambrian age. Unit locally contains cobbles. Boulders as much as $3 \mathrm{ft}$ in diameter in unit at north butte of Oregon Buttes. Interbedded ash beds like unit 70;

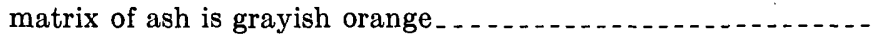

Total thickness of Arikaree Formation

Bridger Formation:

68. Sandstone, dusky-yellow, fine- and medium-grained, crossbedded; some limonite streaks and abundant magnetite; weathers to rounded knobs.

67. Sandstone, yellow-gray, fine-grained, siliceous; contains magnetite; banding cuts bedding; cliff former. . . . . . . . . . . . . . . . . . . .

66. Siltstone, light-olive-gray (weathers grayish orange), finely laminated, varved; contains much organic material and fish scales; fractures unevenly; cliff former. Ashy and fine sand 10 ft above base; becomes more sandy upward . .................

65. Limestone, brownish-gray, fossiliferous; contains ostracodes and cone-in-cone structure at top. . . . . . . . . . . . . . . . . . . . .

64. Sandstone, yellow-gray, fine-grained, biotitic; contains Goniobasis and some limestone layers...................................

63. Sandstone, dusky-yellow, fine-grained...........................

62. Limestone and sandstone, interbedded. Limestone, light-olivegray, sandy; Goniobasis coquina. Sandstone, yellow-gray, fine-grained; a few Goniobasis and pelecypods..................

61. Siltstone and clay, dusky-yellow. Small tooth and wood fragments $30 \mathrm{ft}$ above base. Sandy clay $15 \mathrm{ft}$ above base. 
6. Section of part of the Arikaree Formation, the Bridger Formation, and the Laney Shale Member of the Green River Formation on Oregon Buttes from the center of sec. 14 to the $S W 1 / 4$ sec. 11, T. 26 N., R. $101 \mathrm{~W}$.-Continued

Bridger Formation-Continued

Feet

60. Sandstone and conglomerate, light-olive to yellow-gray, crossbedded. Local pebble to cobble conglomerate channel reaches

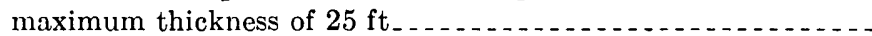

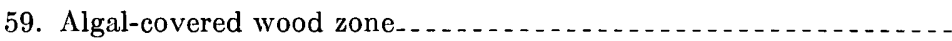

58. Siltstone, dolomitic, fissile; a few ostracodes; sandy $10 \mathrm{ft}$ above base; forms 1-ft ledge at base.

57. Mudstone, grayish-green, tuffaceous, sandy

56. Sandstone, moderatè-yellowish-brown ... . . . . . . . . . . . .

55. Mudstone, grayish-green, tuffaceous, sandy. Bones, Equisetum?, and other small wood stems $5 \mathrm{ft}$ above base. Concretions of fine-grained sandstone 1-2 ft in diameter at base; limonitic;

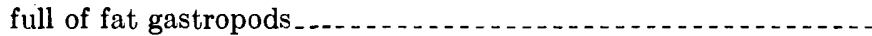

54. Sandstone, moderate-yellowish-brown; some siltstone and clay in lower $5 \mathrm{ft}$

53. Sandstone, light-gray; forms series of $0.1-0.2$-ft ledges $\ldots . . . . . .$.

52. Claystone, greenish-gray, and yellowish-brown sandstone $\ldots . . . .$.

51. Limestone, sandy; contains clay pebbles, ostracodes, Viviparis, Physa?, Goniobasis, Unio, Planorbis?, and teeth?; forms ledge. Algal growths vary thickness of ledge; are silicified at top of bed. Disconformable contact at base with relief of more than 1 foot.

7. 0

55. 0

2. 0

10. 0

50. Sandstone, moderate-yellowish-brown, fine-grained; contains ostracodes and turtle shells. Many black minerals, small (0.25 in.) iron-manganese nodules, and 1- to 2-ft oblong sandstone nodules. Lower $3 \mathrm{ft}$ dusky-yellow shale; mostly clay, some silt..........

49. Sandstone, light-pinkish-gray; bedding nodular; many ostracodes.-

48. Dolomite and claystone, light-pinkish-gray; form two fissile silty ledges; mapped as d bed. Many ostracodes, plant remains, fish plates, turtle bones and plates, and possibly insects. Basal bed has macerated plants, squashed ostracodes, and clay pellets; disconformity at base with relief of $1 \mathrm{ft}$ locally ................

47. Mudstone, grayish-yellowish-green; possibly shell fragments. Cemented nodular bed 1-2 ft from top; limonite stain ........

46. Sandstone, moderate-yellowish-brown, fine-grained with a few medium grains. A 0.2 -ft light-gray sandstone at base forms minute ledge

45. Siltstone, yellowish-gray, clayey; forms flat area . . . . . . . . .

44. Sandstone, moderate-yellowish-brown, medium- and coarsegrained; many dark grains, scattered pebbles between 17 and $25 \mathrm{ft}$ above base; better cemented $10 \mathrm{ft}$ above base; forms nearly vertical cliffs. Silty 0.8 -ft concretions $1 \mathrm{ft}$ above base..-

43. Siltstone, yellowish-gray, fissile in part; forms rounded slope.....

42. Claystone, yellowish-gray, fissile, silty in part...............

41. Sandstone, moderate-yellowish-brown, fine-grained; forms rounded slope.

40. Siltstone, yellowish-gray, fissile; some sand and limy stringers; forms rounded slope; lower $5 \mathrm{ft}$ light gray, fissile . . . . . . . . 
6. Section of part of the Arikaree Formation, the Bridger Formation, and the Laney Shale Member of the Green River Formation on Oregon Buttes from the center of sec. 14 to the SW1/4 sec. 11, T. 26 N., R. $101 \mathrm{~W}$.-Continued

Bridger Formation-Continued

Feet

39. Mostly covered; widely separated outcrops of dusky-yellow sandstone, yellowish-gray siltstone, and moderate-yellowish-brown claystone; fine grained. Top 1-2 ft is a silicified algal limestone; mapped as the " $a$ " bed; contains petrified stumps. Black silicified wood 80 and $30 \mathrm{ft}$ above base. Many plates, bones, crocodile teeth, and turtle remains $15 \mathrm{ft}$ above base. Thin clay with plant fragments and seeds? $10 \mathrm{ft}$ above base. Lowest $5 \mathrm{ft}$ is yellowish-gray papery shale.

38. Siltstone, moderate-yellowish-orange, calcareous, warty undersurface. . . . . .

37. Shale, yellowish-gray, papery; some siltstone; Equisetum? and

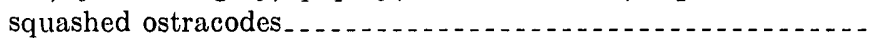

36. Limestone, medium-gray; ostracodes and reddish-brown algal

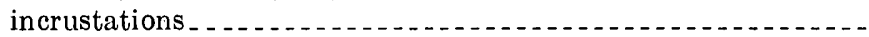

35. Siltstone, yellowish-gray, and sandstone, yellowish-brown; fine

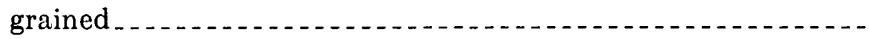

34. Limestone and siltstone, yellowish-gray (weather light yellowish

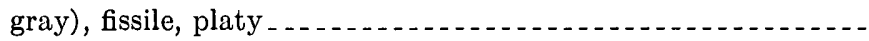

33. Siltstone, yellowish-gray, and sandstone, yellowish-brown, finegrained; bentonitic; unit weathers to a rounded slope.........

32. Siltstone, yellowish-gray; forms slight ledge . . . . . . . . . . . . .

31. Claystone, mottled dusky-yellow to yellowish-gray (weathers dark purplish gray and platy); may be dolomitic . . . . . . . . . . . . .

30. Siltstone, blocky; carbonaceous material; silicified wood surrounded by grayish-orange ashy calcareous algal structures and

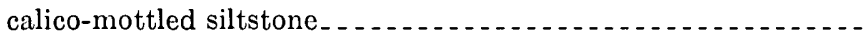

29. Sandstone, grayish-orange, fine-grained. . . . . . . . . . . . .

28. Claystone, olive-brown, silty; contains ostracodes, fish scales, and small pelecypods; weathers to frothy surface. Basal $1 \mathrm{ft}$ is dusky-yellow siltstone containing ostracodes.

26. 0

18. 0

2. 0

4. 0

1. 5

27. Siltstone, pale-olive, fissile; many ostracodes, macerated plant material, and some petrified wood.

26. Claystone, dusky-yellowish-green; contains nodules of grayishyellow bedded platy dolomite $6 \mathrm{in}$. to $2 \mathrm{ft}$ in diameter and silicified tree stumps in upright growth position............

Total thickness of Bridger Formation ...

Green River Formation:

Laney Shale Member:

25. Limestone, grayish- to dark-yellowish-orange; coquina of ostracodes and partly silicified algal structures. . . . . . . . . .

24. Shale, greenish-olive-gray, fissile .

23. Limestone, yellowish-gray (weathers pale yellow brown); algal layers, dense with calcite stringers; ledge former.... 
6. Section of part of the Arikaree Formation, the Bridger Formation, and the Laney Shale Member of the Green River Formation on Oregon Buttes from the center of sec. 14 to the $S W 1 / 4$ sec. 11, T. 26 N., R. $101 \mathrm{~W}$.-Continued

Green River Formation-Continued

Laney Sha'e Member-Continued

22. Siltstone and claystone, dusky-yellow, clayey with much coarse biotite. Claystone, greenish-gray, fissile to platy, $35 \mathrm{ft}$ above base. Claystone, moderate-yellow-brown, silty, $15 \mathrm{ft}$ above base; grades up into fissile claystone. Claystone, pale-olive, blocky, $11 \mathrm{ft}$ above base; thin laminations may be ash falls. Limestone, $0.4 \mathrm{ft}$ thick, clayey, $5 \mathrm{ft}$ above base; contains ostracodes.

21. Limestone, gray; many silt-size black grains . . . . . . . . . .

20. Sandstone, moderate-yellowish-brown, very fine grained; much clay in matrix; fine grains of biotite that form dark bands; forms steep slope

Feet

andstone, light-gray; many black and red grains; has small cavities that may have contained clay fragments.........

18. Claystone, yellowish-gray, hard, dense, varved............

17. Sandstone, light-gray, salt-and-pepper, very fine grained....

16. Siltstone, dusky-yellow, clayey; slope former . . . . . . . . . . .

15. Sandstone, light-gray, very fine grained, vuggy, porous, thinbedded to platy; black and red grains, probably tuffaceous; some ostracode impressions filled with clay; ledge former

14. Sandstone, moderate-yellowish-brown, very fine grained, silty; large flakes of biotite . . . . . . . . . . . . . . . . . . . .

13. Siltstone to very fine grained sandstone, yellowish-gray, limy; contains clay pebbles...........................

12. Sandstone, dusky-yellow, very fine grained, silty, biotitic.-.-

11. Shale, pale-olive, dusky-yellow, and moderate-yellowishbrown, blocky . . . . . . . . . . . . . . . . . . . . . . .

10. Limestone, yellowish-gray (weathers grayish yellow); algal structures, ostracode coquina; forms terrace; stains slope below light gray . . . . . . . . . . . . . . . . . . . . . . .

9. Shale, pale-olive to dusky-yellow, papery; squashed ostracodes on bedding surfaces.

10. 5

.2

1. 0

.5

3. 0

1. 0

5. 0

2. 0

5. 0

5. 0

1. 0

30. 0

8. Limestone, grayish-orange, recrystallized; calcite inclusions; ostracodes.

7. Shale, light-olive-gray, papery

6. Limestone, yellowish-gray (weathers moderate brown), dense, recrystallized; dark-yellow-brown algal balls $0.5-1$ in. in diameter, many replaced by silica; many ostracodes;

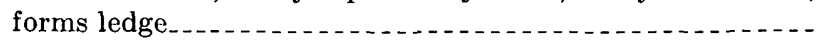

5. Shale, light-olive-gray, papery; squashed ostracodes on

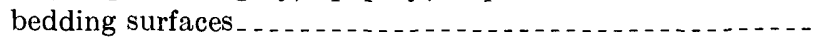

4. Limestone, pinkish-gray, platy; scattered fat ostracodes.-...

3. Sandstone, dusky-yellow to grayish-olive, very fine grained, clayey, friable, micaceous . . . . . . . . . . . . . . . . . .

2. Limestone, pinkish-gray (weathers moderate brown), dense; abundant ostracodes; secondary calcite in vugs; algae, fish scales, and bone fragments..........

11. 0

Total thickness of Laney Shale Member 
6. Section of part of the Arikaree Formation, the Bridger Formation, and the Laney Shale Member of the Green River Formation on Oregon Buttes from the center of sec. 14 to the $S W 1 / 4$ sec. $11, T .26 N ., R .101 \mathrm{~W}$.-Continued

Wasatch Formation:

Cathedral Bluffs Tongue:

1. Mudstone, grayish-yellow-green; scattered quartz grains. Not measured.

7. Section of Laney Shale Member north of Bear Creel between Oregon Buttes and Continental Peak, W1/2 sec. 5, T. 26 N., R. $100 \mathrm{~W}$.

Bridger Formation:

Feet

18. Siltstone, light-greenish-gray, soft, fissile; contains petrified wood.

Green River Formation:

Laney Shale Member:

17. Limestone, light-brown to tan, algal; abundant ostracodes, many petrified logs and stumps; much of the material is silicified

16. Paper shale, light-greenish-gray, gypsiferous and calcareous; some blocky claystone. Algal limestone heads $1 \mathrm{ft}$ in diameter 40 and $60 \mathrm{ft}$ above base. A 1-in. ostracodal limestone $20 \mathrm{ft}$ above base. . . . . . . . . . . . . . . . . . . . .

15. Sandstone, light-greenish-gray, very fine grained, calcareous; contains petrified wood.

14. Paper shale, light-olive-green ... . . .

13. Sandstone, light-greenish-gray (weathers rusty), very fine grained, calcareous, platy to flaggy

12. Covered, probably greenish-gray paper shale

11. Limestone, light-brown to tan, algal; ostracodes...........

10. Siltstone, light-greenish-gray . . . . . . . . . . . . . . . . . .

9. Limestone, light-brown, platy; ostracodes, scattered algal heads.

4. 0

2. 0

11. 0

8. Paper shale, dark-greenish-gray, bentonitic; some light-gray silty very fine sandstone laminae...............

7. Limestone, light-brown to tan, algal; ostracodes..........

6. Paper shale, greenish-gray ..........................

5. Limestone, light-brown, algal; pisolites, ostracodes........

4. Limestone, medium-brown, flaggy; ostracodes..........

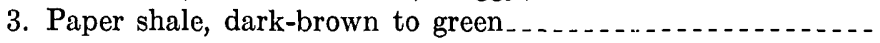

2. Limestone, light-brown to tan; algal heads.........

Total thickness of Laney Shale Member.

Wasatch Formation:

Cathedral Bluffs Tongue:

1. Claystone, green, and dark-brown coarse channel sandstone. Not measured. 
8. Section of parts of the Arikaree and Bridger Formations on the west side of Continental Peak, SE1/4 sec. 35, T. 27 N., R. $100 \mathrm{~W}$.

Arikaree Formation:

10. Conglomerate, medium- to light-gray; contains cobbles and boulders of metamorphic rocks, granite, and graywacke derived

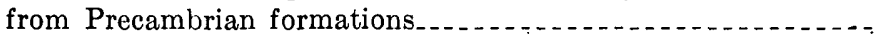

Bridger Formation (in part):

9. Sandstone, light-grayish-orange, fine-grained, ashy. One clay pebble unit $16 \mathrm{ft}$ above base. Two $1-\mathrm{ft}$ siltstone beds $14 \mathrm{ft}$ and

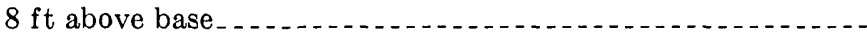

8. Claystone, medium-grayish-green, blocky

7. Sandstone, light-grayish-orange, fine-grained, ashy

6. Claystone, medium-grayish-green to dark-green, blocky; contains many gastropod fillings. Jaw of Orohippus uintanus (Marsh) collected $2 \mathrm{ft}$ above base...............................

5. Sandstone, very fine grained, and siltstone, ashy, rubbly, mottled; weather light grayish pink

4. Siltstone and tuff, light-yellowish-tan to nearly white; contain much biotite; weather rubbly; grade into fine-grained sandstone

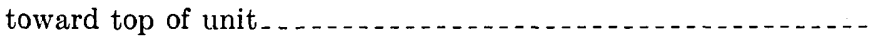

3. Sandstone, light-grayish-green, medium-grained, crossbedded, arkosic; contains many dark grains and scattered clay pebbles; has mud-cracked layers. Weathers into balls about 0.5 in. in

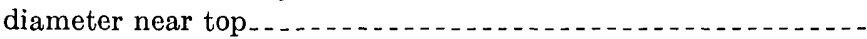

2. Mudstone, siltstone, and fine-grained arkosic sandstone, lightgrayish-green (weather grayish orange and grayish red). Beds contain much volcanic ash, range from 0.5 to $20 \mathrm{ft}$ in thickness, and tend to be massive. Calcareous nodules as much as $2 \mathrm{ft}$ in diameter are common. Upper $40 \mathrm{ft}$ weathers mottled and has many nodules about 1 in. in diameter. A 5 -ft calcareous siltstone $45 \mathrm{ft}$ above base contains a few ostracodes and gastropods. A 5 -ft sandstone $20 \mathrm{ft}$ above base contains clay pebbles..........

1. Sandstone, light-grayish-green (weathers grayish orange), fine- to medium-grained, thin-bedded, ashy; many ostracodes; contains biotite flakes and a few siltstone bands about $0.5 \mathrm{ft}$ thick; tabular and spherical concretions common......... 45

Measured thickness of Bridger Formation ... 299

9. Section of parts of Laney Shale Member of Green River Formation and Cathedral Bluffs Tongue of Wasatch Formation along North Fork Bear Creek in the Honeycomb Buttes, NW1/4 sec. 9, T. 26 N., R. $99 \mathrm{~W}$.

Green River Formation:

Laney Shale Member:

23. Covered, float is siliceous dolomite plates. Top of exposed

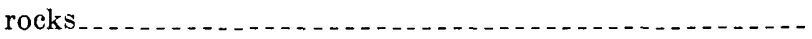

22. Dolomite, light-grayish-tan to brownish-gray, aphanitic,

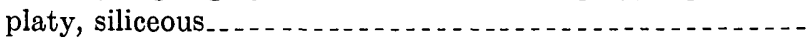


9. Section of parts of Laney Shale Member of Green River Formation and Cathedral Bluffs Tongue of Wasatch Formation along North Fork Bear Creek in the Honeycomb Buttes, NW1/4 sec. 9, T. 26 N., R. 99 W.-Continued

Green River Formation-Continued

Laney Shale Member-Continued

Feet

21. Sandstone and shale. Sandstone, light-yellowish-brown, very fine grained; ostracodes. Shale, medium-brownish-gray,

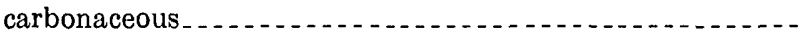

20. Dolomite, light-grayish-tan to brownish-gray, aphanitic,

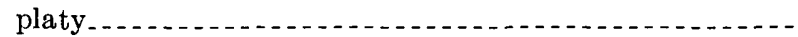

19. Limestone, light-yellowish-gray; contains algal heads and a

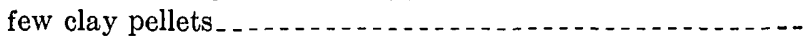

18. Claystone, light-grayish-green, blocky ....................

17. Paper shale, locally kerogenaceous, light-grayish-tan; slope mostly covered; many crushed ostracodes and extremely thin ash beds along laminations. A 1 -ft carbonaceous siltstone $111 \mathrm{ft}$ above base; blocky gray-green claystone from 100 to $111 \mathrm{ft}$ above base; 1-ft algal case containing wood remains $91 \mathrm{ft}$ above base; light-greenish-gray claystone $80 \mathrm{ft}$ above base; some light-olive-tan claystone $40 \mathrm{ft}$ above base; $1.5 \mathrm{ft}$ of light-yellowish-tan limestone containing many ostracodes, oolites, pisolites, and algal rinds around fragments of wood $33 \mathrm{ft}$ above base. Grab sample from $3 \mathrm{ft}$ above base has 2.6 gal oil per ton (U.S. Bur. Mines

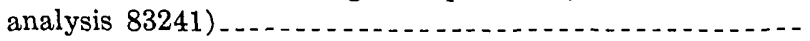

16. Claystone, light-greenish-tan to light-yellowish-gray; probably some tuff present . . . . . . . . . . . . . . . . . . . .

15. Sandstone, light-yellowish-brown to light-olive-brown, very

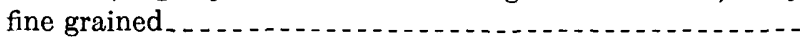

14. Claystone, grayish-green, blocky, fissile; becomes light grayish tan and silty in upper $5 \mathrm{ft}$

13. Paper shale, light-grayish-tan

12. Siltstone, dark-olive-gray; much biotite; weathers bentonitic_

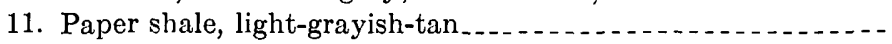

10. Limestone, light-tan, algal; spongelike in appearance; forms beds as much as $1 \mathrm{ft}$ thick which have cavities from 0.5 to 1 in. in diameter.

9. Paper shale, light-grayish-tan ..........

8. Limestone, light-tan, algal; contains ostracodes partly

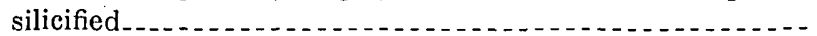

7. Paper shale, light-grayish-tan

6. Limestone, light-tan; contains ostracodes; weathers wormy --

5. Shale, brownish-green, fissile

4. Limestone, light-tan, sandy; contains ostracodes

Measured thickness of Laney Shale Member........ - .

Wasatch Formation:

Cathedral Bluffs Tongue:

3. Claystone, chrome-green, blocky . . . . . . . . . . . .

2. Limestone, light-grayish-tan, algal; contains ostracodes..... -

5. 0

1. Claystone, light-greenish-gray, blocky. Not measured. 
10. Section of part of Bridger Formation and Laney Shale Member of Green River Formation southeast of Reds Cabin monocline from the $S E 1 / 4$ sec. 21 to the $S W 1 / 4$ sec. 22, T. 27 N., R. $101 \mathrm{~W}$.

Bridger Formation (in part) :

21. Sandstone, gray, medium-grained, well-cemented; contains scattered quartz granules; " $a$ " bed at top of hill ..............

20. Covered, probably sandstone; petrified wood float

19. Sandstone, light-bluish-gray, fine-grained.......................

18. Sandstone, like unit 16; forms ledges and slopes.............

17. Sandstone, light-grayish-tan, coarse-grained

16. Sandstone, light-yellowish-brown to grayish-orange-brown, soft, crossbedded.

15. Sandstone, grayish-yellow-brown, fine-grained, fissile, wavybedded to crossbedded; top $0.5 \mathrm{ft}$ contains many nodules about $0.2 \mathrm{ft}$ in diameter.

14. Sandstone, light-gray, fine-grained; forms ledges about $1 \mathrm{ft}$ thick; contains biotite and colored grains; appears to be tuffaceous. Many concretions from 0.2 to $0.5 \mathrm{ft}$ in diameter in top $1 \mathrm{ft}_{\mathrm{t}} \ldots$...

13. Sandstone, light-grayish-yellow and brown, fine- to mediumgrained, thin-bedded, crossbedded. Scattered lenses of grayishorange-brown coarse-grained crossbedded carbonaceous sandstone with many dark grains $5 \mathrm{ft}$ above base .............

Measured thickness of Bridger Formation

Green River Formation:

Laney Shale Member:

12. Shale and siltstone, interbedded. Shale, dark-grayish-green, papery. Siltstone, fissile. Blocky-weathering siltstone in upper $6 \mathrm{ft}$

16. 0

11. Sandstone, grayish and yellowish-brown, fine-grained, thin, wavy-bedded; small lenses of coarse-grained micaceous salt-and-pepper sandstone, probably arkosic. Crushed ostracodes along laminae in upper $5 \mathrm{ft}$; coarse-grained sandgranule conglomerate in lower $0.5 \mathrm{ft}$. Ledges of mediumgrained sandstone as much as $0.2 \mathrm{ft}$ thick

10. Siltstone, dark-grayish-olive-green, fissile; thin beds of paper shale and grayish-yellow-brown fine-grained sandstone...-

9. Shale, grayish-olive-brown, fissile, papery . . . . . . . . . .

8. Sandstone and siltstone. Sandstone, dark-grayish to olivebrown, fine-grained; contains many dark grains. Siltstone yellowish-brown, fissile.

7. Claystone, dark-greenish-brown to brownish-black, fissile to blocky, carbonaceous. ........

6. Claystone; green, blocky-weathering

5. Limestone, light-greenish-gray, argillaceous, nodular. Nodules contain many ostracodes............................

4. Siltstone, dark-olive-green, argillaceous, blocky

3. Limestone, light-yellowish-tan, sandy; weathers ledgy to platy; contains algal heads locally, many Goniobasis and ostracodes 
10. Section of part of Bridger Formation and Laney Shale Member of Green River Formation southeast of Reds Cabin monocline from the SE1/4 sec. 21 to the SW $1 / 4$ sec. 22, T. 27 N., R. 101 W.-Continued

Green River Formation-Continued

Laney Shale Member-Continued

Freet

2. Sandstone, grayish-yellow-brown, fine- to medium-grained. A granule conglomerate near top................. 5.0

Total thickness of Laney Shale Member. . . . . . . . . $\overline{91.4}$

Wasatch Formation:

Cathedral Bluffs Tongue:

1. Claystone, grayish-chrome-green; contains scattered sand grains and quartz and chert pebbles.

11. Section of parts of the South Pass and Bridger Formations south of Monument Draw, $S E 1 / 4$ sec. 31, T. 28 N., R. $102 \mathrm{~W}$.

South Pass Formation (in part):

26. Conglomerate; caps hill. Volcanic ash from $10-12 \mathrm{ft}$ above base.

Coarse grit and pebble conglomerate at base......... 25

Measured thickness of South Pass Formation. . . . . . . . . 25

Bridger Formation (in part):

25. Claystone, moderate-olive, blocky

24. Sandstone, pale-brownish-gray, very fine grained to mediumgrained, clayey, silty; much biotite, red and black grains. Calcareous concretions as much as $2 \mathrm{ft}$ in diameter $14 \mathrm{ft}$ above base; contain manganese dendrites ...........................

23. Siltstone, light-pinkish-gray, clayey; probably tuffaceous.......

22. Sandstone, light-greenish-gray, fine-grained, well-sorted and moderately rounded grains; contains biotite, red and black grains; tends to weather into loosely cemented concretions 4-6 in. in diameter $4 . \mathrm{ft}$ above base. ... ....................

21. Claystone, grayish-olive-green; contains scattered ostracodes...Feet 25

20. Sandstone, light-greenish-gray, very fine grained; contains ostracodes and scattered coarse sand grains $15 \mathrm{ft}$ above base, probably tuffaceous. Thin light-yellowish-gray siltstone $12 \mathrm{ft}$ above base. Concretions about $0.5-1 \mathrm{ft}$ in diameter $7 \mathrm{ft}$ above base..

19. Siltstone, grayish-green, clayey; discontinuous thin streaks of coarse sand and grit.

18. Sandstone and siltstone, light-greenish-gray, very fine grained; contain biotite and red and black grains. ................

17. Claystone, moderate-red-brown; red band near top. . . . . . .....

16. Siltstone, grayish-green, clayey; very clayey $10 \mathrm{ft}$ above base; mottled with red 5 ft above base .........................

15. Sandstone, grayish-yellow-green, coarse-grained, clayey

14. Siltstone, grayish-green, clayey; contains scattered sand grains...

13. Sandstone, like unit 15

12. Siltstone, like unit 14

11. Sandstone, like unit $15 \ldots$

10. Siltstone, like unit 14 
11. Section of parts of the South Pass and Bridger Formations south of Monument Draw, SE1/4 sec. 31, T. 28 N., R. 102 W.-Continued

Bridger Formation (in part)-Continued

9. Sandstone, like unit 15.

8. Siltstone, variegated grayish-green and yellowish-brown; scattered

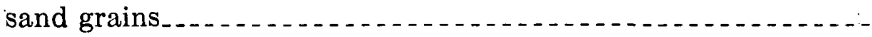

7. Sandstone, light-grayish-green; very coarse grained with scattered granules; medium grained with scattered pebbles near base....

6. Siltstone, grayish-green; contains a few lenses or filled channels of

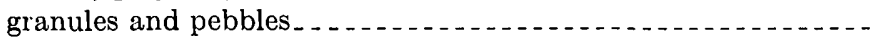

5. Sandstone and granule conglomerate, light-grayish-green, clayey; sparse pebbles; much biotite........ . . . .

4. Siltstone, grayish- to olive-green, clayey; scattered granules.....-

3. Sandstone, grayish-yellow-green, very coarse-grained to coarsegrained; scattered granules and pebbles; clay matrix contains biotite

2. Siltstone, grayish- to olive-green, clayey; scattered coarse sand grains and granules; biotite flakes common........... 10

1. Covered... 5

Measured thickness of Bridger Formation.

12. Section of part of the South Pass Formation about 11/2 miles northwest of the McCann Ranch, SE1/4 sec. 32, T. 28 N., R. $103 \mathrm{~W}$.

South Pass Formation:

Sandstone, light-orangish-gray (weathers moderate grayish orange), fine- to coarse-grained, well-sorted; contains thin to flaggy beds 0.1 in. to several inches thick; many trails and burrows on bedding surfaces; grains of well-rounded quartz and pink garnet; some lightgreen and black grains; some red and brown grains possibly quartzite; mainly dolomite cement that is locally siliceous; exhibits brilliant yellowish-green banding under ultraviolet light

Total thickness of South Pass Formation .

13. Section of parts of the South Pass and Bridger Formations on the east side of a butte about a mile east of Little Sandy Creek, NW1/4 sec. 27, T. 28 N., R. $104 W$.

South Pass Formation (in part):

Feet

10. Conglomerate; mainly derived from Precambrian rocks; sand- to boulder-size constituents in a light-pinkish-gray calcareous matrix characterized by black and red grains and rounded grains of magnetite; strongly crossbedded. Basal $2 \mathrm{ft}$ is reworked Bridger Formation........... $40+$

Measured thickness of South Pass Formation_....... 
13. Section of parts of the Soulh Pass and Bridger Formations on the east side of a butte about a mile east of Little Sandy Creek, NW1/4 sec. 27, T. 28 N., R. 104 W.-Continued

Bridger Formation (in part):

9. Sandstone, volcanic ash, and claystone; poorly exposed. Top 10 $\mathrm{ft}$ fine- to medium-grained sandstone with many red and black grains and an ashy calcareous matrix, crossbedded. Sequence between 75 and $100 \mathrm{ft}$ above base almost pure volcanic ash, white to grayish-white; contains many shard remnants, lapilli 1-3 $\mathrm{mm}$ in diameter, and sand grains. Claystone, light-tannishgray, silty, $20 \mathrm{ft}$ above base. Siltstone, light-grayish-green, biotitic, clayey, $18 \mathrm{ft}$ above base. Claystone, moderate-grayishgreen, blocky, hard; probably dolomitic, $2 \mathrm{ft}$ above base......

8. Claystone, light-grayish-tan, silty; contains scattered medium to coarse sand grains in top $6 \mathrm{ft}$. Top $3 \mathrm{ft}$ is resistant and contains few sand grains; contains vugs and fillings which appear to be ostracode replacements. ...........

7. Sandstone and siltstone. Sandstone, light-bluish-gray, fine-grained to very fine grained; contains calcareous nodules and many root fillings. Siltstone, light-bluish-gray, ashy. Claystone bed, grayish-orange-pink, $2 \mathrm{ft}$ above base....................

6. Claystone, grayish-orange-brown, resistant; contains biotite and yellowish-orange flakes and also clay fragments and manganese-

5. Siltstone, claystone, and sandstone. Siltstone and claystone, light-grayish-brown. Sandstone, light-bluish-gray, very fine grained, ashy; contains calcareous nodules $0.5-3$ in. in diameter. Bed of claystone $5 \mathrm{ft}$ thick, grayish-orange-pink, $45 \mathrm{ft}$ above base

Feet

4. Sandstone, light-bluish-gray, fine- to medium-grained, massivebedded; contains root fillings? and many weathered white to light-gray clay balls as much as $0.5 \mathrm{in}$. in diameter.

3. Siltstone and claystone. Siltstone, light-grayish-brown, probably ashy; shows some cross-laminations. Claystone, light-grayish-

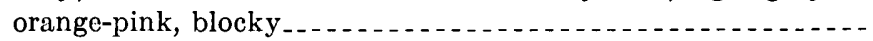

2. Sandstone, light-bluish-gray, medium-grained, crossbedded, dirty, porous, calcareous; coated grains have blue color; numerous medium-size black, red, and green grains and very fine rounded shiny magnetite grains

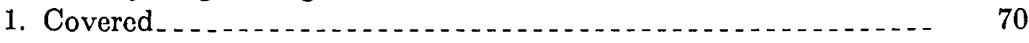

Measured thickness of Bridger Formation.... 304

14. Section of parts of Bridger Formation and Laney Shale Member of the Green River Formation about half a mile east of Little Sandy Creek, SE1/4 sec. 28, T. $28 N$., R. $104 W$.

Bridger Formation (in part):

16. Arkose, light-yellow-gray, coarse-grained; granules and pebbles

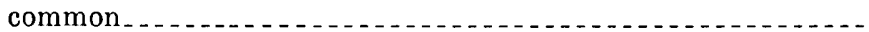

15. Covered slope; probably moderate-yellowish-gray siltstone.....

14. Sandstone, light-yellow-gray, fine-grained, biotitic 
14. Section of parts of Bridger Formation and Laney Shale Member of the Green River Formation about half a mile east of Little Sandy Creek, SE1/4 sec. 28, T. $28 N ., R .104 W .-$ Continued

Bridger Formation (in part)-Continued Feet

13. Covered; probably moderate-yellowish-gray siltstone and very fine sandstone. Limonite concretions $0.25-3$ in. in diameter in float

12. Sandstone, gray, medium- to coarse-grained; many black, green, and red grains, scattered mica grains, and a few limonite concretions about 3-5 $\mathrm{mm}$ in diameter. . . . . . . . . . . . . .

11. Siltstone, moderate-yellowish-gray

10. Shale, light-orange-brown, fissile; fossil log about $5 \mathrm{ft}$ above base

9. Limestone, moderate-orange-brown, dense; algal rinds on black petrified wood, ostracodes. . .

8. Covered

7. Siltstone and sandstone, light-greenish-gray, thin-bedded, wavybedded, calcareous; fish scales. Sandstone, very fine grained with scattered coarse grains and biotite.........

6. Covered.

Green River Formation:

Laney Shale Member (in part):

5. Covered

4. Shale, moderate-grayish-green, fissile..................

3. Limestone, moderate- to light-orangish-gray; ostracodes and gastropods common

2. Sandstone, light-gray, fine-grained, biotitic; ostracodes and fish remains; ledge former.

1. Siltstone, greenish-brown, fissile.

Measured thickness of Laney Shale Member.

15. Section of part of Laney Shale Member of Green River Formation on southeast side of Squaw Teat, NE/4 sec. 32, T. 28 N., R. $104 \mathrm{~W}$.

Green River Formation:

Laney Shale Member (in part):

8. Sandstone, light-gray to moderate-grayish-brown, finegrained to very coarse grained, poorly sorted, thick-bedded, wavy- to massive-bedded; material of granule and pebble size; composed of quartz and rare dark grains, grayish-orange ashy matrix; contains scattered ostracodes and possibly pelecypods; forms slope with discontinuous ledges of very calcareous and ashy rock. A 2 -ft dirty ashy sandstone which weathers to $3-5-\mathrm{mm}$ balls $8 \mathrm{ft}$ above base; balls commonly welded into heads $5-8$ in. in diameter........ 
15. Section of part of Laney Shale Member of Green River Formation on southeast side of Squaw Teat, NE1/4 sec. 32, T. 28 N., R. $104 \mathrm{~W}$.-Continued

Green River Formation-Continued

Laney Shale Member (in part)-Continued

7. Limestone, light-brownish-gray, clayey to sandy, biotitic; beds $2-6$ in. thick; contains hash of fish remains and small pelecypods and ostracodes interbedded with light-greenishgray fine-grained thin-bedded ashy sandstone, much biotite, and medium-grayish-brown biotitic siltstone containing many ostracodes.........................

6. Sandstone, moderate-grayish-orange-brown, fine- to coarsegrained, calcareous, wavy-bedded; much biotite and 'a few ostracodes.

5. Siltstone to very fine grained sandstone, light- to moderatebrownish-gray

4. Paper shale, moderate-grayish-brown; many squashed ostracodes on bedding planes; grades upward into clayey siltstone

3. Sandstone, light-greenish-gray to light-gray, fine-grained, clayey, calcareous; contains biotite, scattered coarse sand grains, and ostracodes. ..............................

2. Siltstone, moderate-grayish-brown, clayey, fissile; contains many small ostracodes; grades into overlying bed........

Measured thickness of Laney Shale Member

Wasatch Formation:

Cathedral Bluffs Tongue:

1. Claystone, moderate-grayish-yellow-green, very sandy, blocky; sand grains angular and subrounded; interval contains many thin yellow-brown medium- to coarsegrained sandstone lenses.

\section{SELECTED REFERENCES}

Bayley, R. W., 1965a, Geologic map of the South Pass City quadrangle, Fremont County, Wyoming: U.S. Geol. Survey Geol. Quad. Map GQ-458.

$1965 \mathrm{~b}$, Geologic map of the Atlantic City quadrangle, Fremont County, Wyoming: U.S. Geol. Survey Geol. Quad. Map GQ-459.

Berg, R. R., 1962, Mountain flank thrusting in Rocky Mountain foreland, Wyoming and Colorado: Am. Assoc. Petroleum Geologists Bull., v. 46, no. 11, p. 2019-2032.

Bradley, W. H., 1926, Shore phases of the Green River Formation in northern Sweetwater County, Wyoming: U.S. Geol. Survey Prof. Paper 140-D, p. 121-131, pls. 58-62.

- 1929a, Algae reefs and oolites of the Green River formation: U.S. Geol. Survey Prof. Paper 154-G, p. 203-223.

$1929 b$, The varves and climate of the Green River epoch : U.S. Geol. Survey Prof. Paper 158-E, p. 87-110.

1961, Geologic map of a part of southwestern Wyoming and adjacent states: U.S. Geol. Survey Misc. Geol. Inv. Map I-332.

1963, Continental Divide-Split: Geotimes, v. 8, no. 3, p. 26. 
Bradley, W. H., 1964, Geology of Green River Formation and associated Eocene rocks in southwestern Wyoming and adjacent parts of Colorado and Utah: U.S. Geol. Survey Prof. Paper $496-\mathrm{A}, 86 \mathrm{p}$.

Burk, C. A., 1955, Green River basin penetration chart, in Wyoming Geol. Assoc. Guidebook, 10th Ann. Field Conf., Green River Basin, 1955 : p. 141.

Comstock, T. B., 1874, Geological report, in Jones, W. A., 1874, Report upon the reconnaissance of northwestern Wyoming made in the summer of 1873: U.S. 43 Cong., 1st sess., H. Ex. Doc. 285, p. 85-184.

Denson, N. M., 1965, Miocene and Pliocene rocks of central Wyoming, in Cohee, G. V., and West, W. S., Changes in stratigraphic nomenclature by the U.S. Geological Survey 1964: U.S. Geol. Survey Bull. 1224-A, p. A70-A74.

Denson, N. M., Zeller, H. D., and Stephens, E. V., 1965, South Pass Formation on the southwest flank of Wind River Mountains, Wyoming, in Cohee, G. V., and West, W. S., Changes in stratigraphic nomenclature by the U.S. Geological Survey 1964: U.S. Geol. Survey Bull. 1224-A, p. A27-A29.

Driggs, H. R., 1942, Westward America : New York, Somerset Books, Inc., 312 p.

Endlich, F. M., 1879, Report on the geology of the Sweetwater district: U.S. Geol. and Geog. Survey Terr. (Hayden), 11th Ann. Rept., p. 3-158.

Fremont, J. C., 1845, Report of the exploring expedition to the Rocky Mountains in the year 1842, and to Oregon and North California in the years 1843-44: Washington, Gales and Seaton (printers), $693 \mathrm{p}$.

Gazin, C. L., 1959, Paleontological exploration and dating of the early Tertiary deposits in basins adjacent to the Uinta Mountains, in Intermountain Assoc. Petroleum Geologists Guidebook, 10th Ann. Field Conf., Guidebook to the geology of the Wasatch and Uinta Mountains transition area, 1959: p. 131-138.

1962, A further study of the lower Eocene mammalian faunas of southwestern Wyoming: Smithsonian Misc. Colln., v. 144, no. 1, 98 p.

Hayden, F. V., 1869, Preliminary field report [third annual] of the U.S. Geol. Survey of Colorado and New Mexico: Washington, U.S. Govt. Printing Office, 155 p. (repr. 1873, p. 103-251).

Irving, Washington, 1850, Adventures of Captain Bonneville: London, George Routledge and Co., $217 \mathrm{p}$.

Jenkins, C. E., 1955a, The Pacific Creek deep test, Superior Oil Company no. 1 unit, sec. 27, T. 27 N., R. 103 W., Sublette County, Wyoming, in Wyoming Geol. Assoc. Guidebook, 10th Ann. Field Conf., Green River Basin, 1955: p. 153-154.

1955b, Pinedale anticline, Sublette County, Wyoming, in Wyoming Geol. Assoc. Guidebook, 10th Ann. Field Conf., Green River Basin, 1955 : p. 155-156.

Knight, S. H., 1955, Review of the early geological explorations of the Green River Basin area 1812-1879, in Wyoming Geol. Assoc. Guidebook, 10th Ann. Field Conf., Green River Basin, 1955: p. 10-17.

Love, J. D., 1954, Periods of folding and faulting during Late Cretaceous and Tertiary time in Wyoming [abs.] : Am. Assoc. Petroleum Geologists Bull., v. 38 , no. 6, p. 1311-1312.

1961, Split Rock formation (Miocene) and Moonstone formation (Pliocene) in central Wyoming: U.S. Geol. Survey Bull. 1121-I, 36 p.

Love, J. D., Weitz, J. L., and Hose, R. K., 1955, Geologic map of Wyoming: U.S. Geol. Survey.

McGrew, P. O., and others, 1959, The geology and paleontology of the Elk Mountain and Tabernacle Butte area, Wyoming: Am. Mus. Nat. History Bull., v. 117, art. 3, p. 117-176. 
Morris, W. J., 1954, An Eocene fauna from the Cathedral Bluffs tongue of the Washakie basin, Wyoming: Jour. Paleontology, v. 28, no. 2, p. 195-203.

Moss, J. H., 1951, Early Man in the Eden Valley [Wyoming] : Philadelphia, Univ. of Pennsylvania Mus., $124 \mathrm{p}$.

Nace, R. L., 1939, Geology of the northwest part of the Red Desert, Sweetwater and Fremont Counties, Wyoming: Wyoming Geol. Survey Bull. 27, 51 p., $1 \mathrm{pl}$.

Peale, A. C., 1879, Report on the geology of the Green River district [Wyoming] : U.S. Geol. and Geog. Survey Terr. (Hayden), 11th Ann. Rept., p. 509-646.

Pipiringos, G. N., 1961, Uranium-bearing coal in the central part of the Great Divide Basin : U.S. Geol. Survey Bull. 1099-A, 104 p.

Read, G. W., and Gaines, Ruth, eds., 1949, Gold Rush, the journals, drawings, and other papers of J. Goldsborough Bruff, April 2, 1849-July 20, 1851: New York, Columbia Univ. Press, $794 \mathrm{p}$.

Richmond, G. M., 1945, Geology of northwest end of the Wind River Mountains, Sublette County, Wyoming: U.S. Geol. Survey Oil and Gas Inv. (Prelim.) Map 31.

Schultz, A. R., 1920, Oil possibilities in and around Baxter Basin, in the Rock Springs uplift, Sweetwater County, Wyoming: U.S. Geol. Survey Bull. 702, $107 \mathrm{p} ., 17 \mathrm{pls}$.

Stansbury, Howard, 1853, Exploration and survey of the valley of the Great Salt Lake of Utah, including a reconnaissance of a new route through the Rocky Mountains : U.S. 32d Cong., spec. sess., S. Ex. Doc. 3, 487 p.

Thurman, F. A., 1950, Sketches of early Wyoming, in Wyoming Geol. Assoc. Guidebook, 5th Ann. Field Conf., Southwestern Wyoming, 1950: p. 13-16.

Wood, H. E., and others, 1941, Nomenclature and correlation of North American continental Tertiary : Geol. Soc. America Bull., v. 52, no. 1, p. 1-48.

Writers' Program, Wyoming, 1941, Wyoming; a guide to its history, highways, and people; New York, Oxford University Press, $490 \mathrm{p}$.

Wyoming Geological Association, 1955, Guidebook 10th Ann. Field Conf., Green River Basin : $243 \mathrm{p}$.

Zeller, H. D., and Stephens, E. V., 1964a, Geology of the NE1/4 of the Essex Mountain quadrangle, Sweetwater County, Wyoming: U.S. Geol. Survey Mineral Inv. Field Studies Map MF-285.

- 1964b, Geology of the Pinnacles NW quadrangle, Sweetwater County, Wyoming: U.S. Geol. Survey Mineral Inv. Field Studies Map MF-286.

- 1964c, Geology of the NE1/4 of the Freighter Gap quadrangle, Sweetwater County, Wyoming: U.S. Geol. Survey Mineral Inv. Field Studies Map MF-288.

- 1964d, Geology of the NW1/4 of the Freighter Gap quadrangle, Sweetwater County, Wyoming: U.S. Geol. Survey Mineral Inv. Field Studies Map MF-289.

1964e, Geologic map of the Continental Peak quadrangle, Fremont and Sweetwater Counties, Wyoming: U.S. Geol. Survey Mineral Inv. Field Studies Map MF-292.

- 1964f, Geologic map of the Dickie Springs quadrangle, Fremont and Sweetwater Counties, Wyoming: U.S. Geol. Survey Mineral Inv. Field Studies Map MF-293.

$1964 \mathrm{~g}$, Geologic map of the Pacific Springs quadrangle, Fremont and Sweetwater Counties, Wyoming: U.S. Geol. Survey Mineral Inv. Field Studies Map MF-294. 
Zeller, H. D., and Stephens, E. V., 1964h, Geologic map of the Hay Meadow Reservoir quadrangle, Sublette, Fremont, and Sweetwater Counties, Wyoming: U.S. Geol. Survey Mineral Inv. Field Studies Map MF-295.

1964i, Geologic map of the Parting of the Ways quadrangle, Sublette and Sweetwater Counties, Wyoming: U.S. Geol. Survey Mineral Inv. Field Studies Map MF-296.

1964j, Geologic map of the Tule Butte quadrangle, Sweetwater County, Wyoming: U.S. Geol. Survey Mineral Inv. Field Studies Map MF-297. 


\section{N D E X}

[Italic page numbers Indicate major references]

\begin{tabular}{|c|c|}
\hline 8 & ag \\
\hline cknowledgments. & Viviparis. \\
\hline gates.. & Viviparus paludinaeiform \\
\hline Cree & Washakius insignis \\
\hline lluvium........ & rontier Formation. . \\
\hline $\begin{array}{r}\text { ikaree Formation } \ldots \ldots \ldots \ldots \ldots \ldots \ldots . \ldots 20,22,26,38 \\
\text { measured section. } \ldots \ldots \ldots \ldots \ldots \ldots \ldots \ldots \ldots . . \ldots \ldots \ldots \\
43,48\end{array}$ & Gazin, C. L., quoted... \\
\hline tiodactyla & Geologic history \\
\hline axter Shale Formation. & Gosiute Lake................ \\
\hline .......... & Granite Mountains........... \\
\hline g Sandy Creek................. & $8,26,27,30$ \\
\hline (n.............. & 6,26 \\
\hline (n............... & -. $2,8,17,18,27,30,38$ \\
\hline oars Tusk & $\ldots 12,15,31$ \\
\hline $\begin{array}{l}\text { rmation } \ldots \ldots \ldots \ldots \ldots .18,20,21,22,26,31 \\
\text { red section } \ldots \ldots \ldots \ldots, \ldots 3,47,48,50,51,53\end{array}$ & $40,42,45,47,48,50,54$ \\
\hline 24 & $\begin{array}{l}\text { Hay syncline... } \\
\text { Historical sketcl }\end{array}$ \\
\hline athedral Bluffs Ton & Buttes.............. \\
\hline $12,16,18$ & Honey \\
\hline$\$ 2$ & \\
\hline 34 & $6,16,17,24$ \\
\hline ollu & Joe $\mathbf{H a}$ \\
\hline (n) & \\
\hline (n) & $\gamma_{i}$ \\
\hline$-18,21,23,27,30,38$ & Kil \\
\hline ......... 26,31 & H., quoted. \\
\hline $16,18,20,26,27$ & Lance \\
\hline ormation.................. & Land \\
\hline & rk \\
\hline Dry & 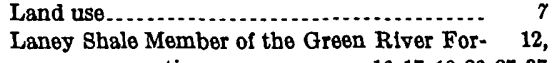 \\
\hline 32 & $8,26,27,37$ \\
\hline Emig & lon \\
\hline 27 & 6,24 \\
\hline iftee & lity..... \\
\hline ...... & \\
\hline . . . . $10,29,32$ & - 28,38 \\
\hline ossils & \\
\hline ...... $14,15,44$ & \\
\hline & tddle Hay Ranch......... \\
\hline ..... & \\
\hline & Torth Platte Ri \\
\hline & \\
\hline & \\
\hline & \\
\hline & assays from Pinnacles $1 \mathrm{~A}$ cor \\
\hline & \\
\hline$\ldots$ & $6 \quad 6,24$ \\
\hline & 28 \\
\hline
\end{tabular}


Page

Pathfinder Reservoir

Pearlette Ash Member of the Sappa Formation...........................

Pediment gravels...................................

Physical features.

Pinedale anticline.

Pinyon Conglomerate.

Powder River Basin.

Precambrian rocks.

Previous investigations.

Prospect Mountains.

Quaternary rocks

Red Desert.

Reds Cabin monocline

Rock Springs anticline

Rock Springs uplift

Sand.

Sand Creek

Scope of investigation

Selected references

Settlement .

South Packsaddle Canyon

South Pass.

South Pass Formation

measured section

Split Rock Formation

Squaw Teat

Stansbury, Howard, quoted

Stratigraphic sections.
6 26
Page

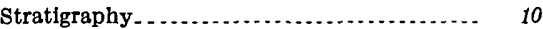

Stream gravel ............................. 24

Structural features........................... 27

Sweetwater River........................ 6,23

Table Mountain ............................. 9

Terrace gravels..................... 26

Tertiary rocks.............................. 12

Tipton Shale Member of the Green River

Formation....

Uinta Formation. ......................... 20

Upper Chadron members of the Chadron

Eranium Formation...................... 21

Vegetation .................................... 6

Wamsutter arch......................... 14

Wasatch Formation.......... 10, 14, 24, 27, 30, 31, 32 main body............................ 12 measured section................ 42, 47, 49, 55

Washakie Basin............................ $\quad 30$

Whitehorse Creek ............................ 6

White Mountain ............................ 26

White River Formation................... 23

Whitmore, F. C., quoted.................. 22

Wildlife

Wilkins Peak Member of the Green River Formation................ 12, 17, 18, 37

Wind River Range............... 2, 10, 23, 26, 30, 31

Wind River thrust fault...................... 27. 30 